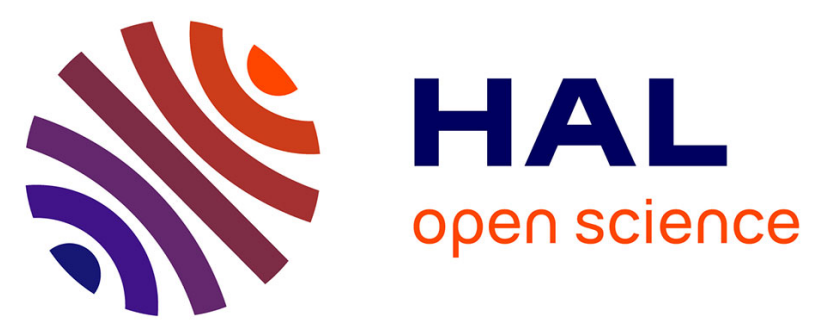

\title{
ALISKIREN AFFECTS FATTY-ACID UPTAKE AND LIPID-RELATED GENES IN RODENT AND HUMAN CARDIOMYOCYTES.
}

\author{
Diego Rodríguez-Penas, Sandra Feijóo-Bandín, Pamela V Lear, Ana
}

Mosquera-Leal, Vanessa García-Rúa, Manuel F Otero, Miguel Rivera, Oreste

Gualillo, José Ramón González-Juanatey, Francisca Lago

\section{To cite this version:}

Diego Rodríguez-Penas, Sandra Feijóo-Bandín, Pamela V Lear, Ana Mosquera-Leal, Vanessa GarcíaRúa, et al.. ALISKIREN AFFECTS FATTY-ACID UPTAKE AND LIPID-RELATED GENES IN RODENT AND HUMAN CARDIOMYOCYTES.. Biochemical Pharmacology, 2011, 82 (5), pp.491. 10.1016/j.bcp.2011.05.021 . hal-00721645

\section{HAL Id: hal-00721645 https://hal.science/hal-00721645}

Submitted on 29 Jul 2012

HAL is a multi-disciplinary open access archive for the deposit and dissemination of scientific research documents, whether they are published or not. The documents may come from teaching and research institutions in France or abroad, or from public or private research centers.
L'archive ouverte pluridisciplinaire HAL, est destinée au dépôt et à la diffusion de documents scientifiques de niveau recherche, publiés ou non, émanant des établissements d'enseignement et de recherche français ou étrangers, des laboratoires publics ou privés. 


\section{Accepted Manuscript}

Title: ALISKIREN AFFECTS FATTY-ACID UPTAKE AND LIPID-RELATED GENES IN RODENT AND HUMAN CARDIOMYOCYTES.

Authors: Diego Rodríguez-Penas, Sandra Feijóo-Bandín, Pamela V Lear, Ana Mosquera-Leal, Vanessa García-Rúa,

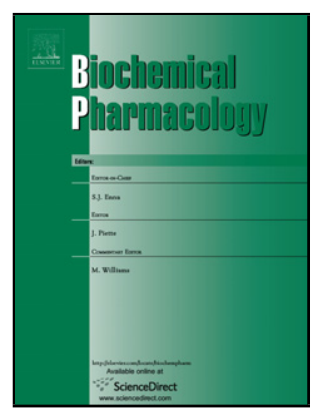

Manuel F Otero, Miguel Rivera, Oreste Gualillo, José Ramón

González-Juanatey, Francisca Lago

PII:

S0006-2952(11)00334-0

DOI: doi:10.1016/j.bcp.2011.05.021

Reference:

BCP 10913

To appear in: $\quad B C P$

Received date: $\quad 19-1-2011$

Revised date: 13-5-2011

Accepted date: $\quad$ 18-5-2011

Please cite this article as: Rodríguez-Penas D, Feijóo-Bandín S, Lear PV, MosqueraLeal A, García-Rúa V, Otero MF, Rivera M, Gualillo O, González-Juanatey JR, Lago F, ALISKIREN AFFECTS FATTY-ACID UPTAKE AND LIPID-RELATED GENES IN RODENT AND HUMAN CARDIOMYOCYTES., Biochemical Pharmacology (2010), doi:10.1016/j.bcp.2011.05.021

This is a PDF file of an unedited manuscript that has been accepted for publication. As a service to our customers we are providing this early version of the manuscript. The manuscript will undergo copyediting, typesetting, and review of the resulting proof before it is published in its final form. Please note that during the production process errors may be discovered which could affect the content, and all legal disclaimers that apply to the journal pertain. 


\section{ALISKIREN AFFECTS FATTY-ACID UPTAKE AND LIPID-RELATED GENES IN RODENT AND HUMAN CARDIOMYOCYTES.}

Diego Rodríguez-Penas, ${ }^{1}$ * Sandra Feijóo-Bandín, ${ }^{1}$ Pamela V Lear, ${ }^{1}$ * Ana Mosquera-Leal, ${ }^{1}$ Vanessa García-Rúa, ${ }^{1}$ Manuel F Otero, ${ }^{1}$ Miguel Rivera, ${ }^{2}$ Oreste Gualillo, ${ }^{3}$ José Ramón GonzálezJuanatey, ${ }^{1}$ Francisca Lago. ${ }^{1 \rrbracket}$

*These authors contributed equally.

${ }^{1}$ Cellular and Molecular Cardiology Research Unit, Department of Cardiology and Institute of Biomedical Research, and ${ }^{3}$ Neuroendocrine Interactions in Rheumatic Diseases Laboratory, Institute of Biomedical Research, University Clinical Hospital, Santiago de Compostela, Spain;

${ }^{2}$ Cardiocirculatory Unit, Research Center, La Fe University Hospital, Valencia, Spain.

\section{${ }^{\mathbb{I}}$ CORRESPONDENCE: Dr Francisca Lago}

Laboratorio 7, Instituto de Investigaciones Sanitarias de Santiago de Compostela (IDIS),

Planta -2, Edificio de Consultas Externas, Hospital Clínico Universitario, Travesía Choupana s/n, 15706 Santiago de Compostela, Spain.

Tel: + 34981950902

Fax: +34981950905

Email: Francisca.Lago.Paz@sergas.es

SHORT TITLE: Aliskiren affects cardiomyocyte metabolism.

KEY WORDS: Cardiomyocytes, aliskiren, metabolism, lipids, cholesterol, glucose. 


\begin{abstract}
PURPOSE: We investigated whether the direct renin inhibitor aliskiren can affect metabolism in cardiomyocytes from rat, mouse and human sources. METHODS AND RESULTS: At 10$50 \mu \mathrm{mol} / \mathrm{L}$, aliskiren significantly increased medium-chain-fatty-acid uptake in primary-cultured neonatal-rat and HL-1 adult-mouse-derived cardiomyocytes (BODIPY-induced fluorescence intensity). The fatty-acid transporter CD-36 was correspondingly translocated to, but the glucose transporter Glut-4 away from, the sarcoplasmic reticulum/plasma membrane, in primary-cultured neonatal-rat (CD-36, Glut-4) and adult-human (CD-36) cardiomyocytes (confocal immunocytochemistry). Immunoblotting showed that aliskiren induced phosphorylation of ERK1/2 in cardiomyocytes from all three sources; responses were dose- and time-dependent, unaffected by renin treatment, and did not cause alterations in expression of (P)R or Igf2/M6P receptors. Microarray analysis of the complete genome of aliskiren-treated neonatal-rat cardiomyocytes, with RT-qPCR and immunoblot confirmation assays in rat and human primary cardiomyocytes, showed that aliskiren up-regulated mRNA and increased protein expression of several enzymes important in lipid and glucose metabolism and in cholesterol biosynthesis. Cardiomyocyte cell-cycle and viability were unaffected by aliskiren. CONCLUSIONS: Aliskiren can induce changes in fatty-acid and glucose uptake and expression of key enzymes of lipid and cholesterol metabolism, which are not associated with increased expression of (P)R or Igf2/M6P receptors, in cultured cardiomyocytes.
\end{abstract}




\section{Introduction}

Aliskiren is the first clinically effective anti-hypertensive agent to have been developed by molecular modelling and to work by direct renin inhibition (DRI) in the renin-angiotensinaldosterone system (RAAS) [1-4]. Approved by the US FDA in 2007, aliskiren produces sustained suppression of plasma renin activity when used in monotherapy in hypertensive patients $[5,6]$, of cardiac angiotensin in spontaneously hypertensive rats [7], and of renal angiotensin in human renal podocytes [8]. In addition to its targetted anti-hypertensive action, aliskiren shares with angiotensin-converting enzyme (ACE) inhibitors and angiotensin-receptor blockers (ARBs) effects considered to be angiotensin- and blood-pressure-independent, notably cardiovascular and renal protection, in hypertensive rats [7,9] and patients [2,4,10-12].

However, while ACE inhibitors and ARBs have some relatively minor differences in such nonanti-hypertensive effects, several studies suggest that those of the DRI aliskiren are significantly different in several ways [7,9-11]. First, aliskiren's cardiovascular [2,7,9] and renal $[2,4,12,13]$ protection appear to be more complete, and possibly attributable to as-yet uncharacterised novel means $[14,15]$. A recent report shows that aliskiren is able to reduce atherogenesis in mice independent of anti-hypertensive effects [16]. Second, aliskiren also appears to be functionally beneficial or protective in other tissues (pancreatic $\beta$-cell epithelium $[17,18]$, white adipose [18], immune and nervous tissues [19]) and might even reverse end-organ damage [3,7,20]. Third, DRI appears to have haemodynamic effects, in spontaneously hypertensive rats [7], in healthy humans on a low-sodium diet [21], and in patients with congestive heart failure [22]. Fourth, aliskiren's organ-protective effects have been particularly noted in a background of diabetes mellitus $[2,17,23,24]$, suggesting that it has one or more metabolic actions. Interestingly, recent clinical studies have found aliskiren to be more effective than ACE inhibitors or ARBs at lowering blood pressure and improving insulin sensitivity in hypertensive patients with metabolic syndrome $[6,25]$. 
Metabolic syndrome is prevalent in hypertensive patients and strongly associated with cardiovascular myopathies [26,27], while chronically elevated RAAS is implicated in many features of metabolic syndrome [6]. The complexity of RAAS is evidenced by the discovery that binding of (pro)renin to the (pro)renin receptor ((P)RR) [28] can produce non-angiotensin-IImediated effects which are not inhibited by aliskiren [29-31]. This latter finding underpins the concept that renin can act not only as an enzyme but also as a hormone $[10,20]$, providing a putative mechanism for non-blood-pressure-related effects of all three classes of RAAS inhibitor, and thus important insights into how to combine different RAAS inhibitors in tailored therapies $[3,10,32]$. Yet, only five studies to date $[7,9,17,32,33]$ have focussed on the cellular or molecular mechanisms underlying organ protection by aliskiren, and none have directly investigated the role(s) that metabolism might play.

Therefore, while it has been suggested that the use of aliskiren could add potential metabolic benefits over other RAAS inhibitors, basic and clinical studies are still necessary to find a mechanism that could link direct renin inhibition with metabolic regulation by this drug [34]. In the current study, we have investigated some of aliskiren's metabolic effects in cardiomyocytes and determined whether they correlate with changes in expression of $(\mathrm{P}) \mathrm{Rr}$ or the insulin-like growth factor II/mannose-6-phosphate (Igf2/M6P) receptor, which can also internalise pro-renin and activate it to renin [35]. In the absence of previous studies, our focus has been on cardiomyocytes from rodent and human sources.

\section{Methods}

All reagents were from Sigma Chemical Co (MO, USA) unless otherwise stated. 


\section{Cardiomyocyte cultures, cell-viability/cell-cycle assays, and metabolic assays}

HL-1 and primary cultures of neonatal-rat cardiomyocytes were cultured as previously [36]. The investigation conforms with the Guide for Care and Use of Laboratory Animals published by the US National Institutes of Health (NIH Publication No. 85-23, revised 1996). Approval for the harvesting and use of cardiomyocytes from neonatal rats was also granted by the University of Santiago de Compostela Ethics Review Board. Human cardiomyocytes (HCM) were obtained from Promocell GmbH (Heidelberg, Germany) and cultured according to the supplier's instructions. Tissue used by PromoCell for the isolation of HCM is obtained from donors with informed consent (by the donor or legally authorized agent) which includes the purpose of the donation and the procedure for processing the tissue. PromoCell acts in strict compliance with the following: the Convention for Protection of Human Rights and Dignity of the Human Being with Regard to the Application of Biology and Medicine: Convention of Human Rights and Biomedicine (4 April, 1997, Council of Europe (European Treaty Series - no 164), the Human Tissue Act (15 November 2004, HM Government, United Kingdom (this Act aims to make consent a fundamental principle underpinning the use and storage of human tissue), and the Declaration of Helsinki.

Due to patient confidentiality PromoCell does not supply clinical information except that that the donors were not known to have any chronic disease. PromoCell states that: i.) their HCM are suitable for in vitro studies of cardiac diseases such as hypertrophy and for physiological and pharmacological studies; ii.) in contrast to freshly isolated myocytes, cultured HCM may be used for longer term experiments such as investigating the effects of cytokines, mechanical strain, or cell-cell interactions; iii.) the HCM have been tested immunohistochemically for cell-type-specific markers, including: sarcomeric alpha-actinin positive, slow muscle myosin positive, CD-90 negative; iv.) rigorous quality-control tests are performed on each lot of PromoCell HCM, including for cell morphology, adherence rate, and viability; v.) growth performance is tested through multiple passages up to 15 population doublings (PD) under culture conditions without 
antibiotics or antimycotics; vi.) all cells have been tested for the absence of HIV-1, HBV, HCV, and microbial contaminants (fungi, bacteria, mycoplasma).

The range of doses of aliskiren $(1 \mathrm{nmol} / \mathrm{L}-50 \mu \mathrm{mol} / \mathrm{L})$ was chosen on the basis of previous reports [37,38]. For 3-[4,5-dimethylthiazol-2-yl]-2,5-diphenyltetrazolium bromide (MTT) mitochondrial metabolic activity assays [36], serum-deprived HL- 1 cardiomyocytes (10 $4 / \mathrm{P} 96$ well) were treated for 24 or $48 \mathrm{~h}$ with aliskiren (a gift from Novartis Pharmaceuticals SA, Spain) and fetal bovine serum (FBS) was used as a positive control due to its induction of cell proliferation. For cellviability assays [36] serum-deprived HL-1 cells (4×105/P96 well) were treated for $24 \mathrm{~h}$ with 1 $50 \mu \mathrm{mol} / \mathrm{L}$ aliskiren. For fatty-acid uptake experiments, serum-deprived HL-1 cells or primarycultured neonatal-rat cardiomyocytes $\left(4 \times 10^{5} / \mathrm{P} 6\right.$ well) were treated for 30 (HL-1) or $120 \mathrm{~min}$ (rat) with aliskiren $(1-50 \mu \mathrm{mol} / \mathrm{L})$ or insulin $(0.1 \mu \mathrm{mol} / \mathrm{L}$, positive control $)$ in PBS containing $10 \mu \mathrm{mol} / \mathrm{L}$ 4,4-difluoro-5-methyl-4-bora-3a,4a-diaza-s-indacene-3-dodecanoic acid (BODIPY® 500/510 C1, C12; Molecular Probes, OR, USA) and 20 $\mu \mathrm{mol} / \mathrm{L}$ fatty-acid-free BSA. Cells were also stained with propidium iodide $(1 \mu \mathrm{mol} / \mathrm{L})$ to identify dead cells, and analyzed in a FACSCALIBUR flow cytometer (Becton Dickinson, CA, USA) using the Cell Quest program.

\section{Immunocytochemistry and confocal microscopy}

Serum-deprived primary-cultured neonatal-rat (10\%/coverslip/P24 well) or adult-human (7000/well in Lab-Tek®II Chamber Slides; Nunc, Denmark) cardiomyocytes were treated with 10 or $50 \mu \mathrm{mol} / \mathrm{L}$ aliskiren for 15 or $30 \mathrm{~min}$, and fixed for $20 \mathrm{~min}$ in $4 \%$ paraformaldehyde/PBS. Cells were then permeabilised and blocked in PBS containing 0.2\% tween-20, 5\% heat-inactivated normal goat serum and $0.2 \%$ electrophoresis-grade BSA, to which anti-CD-36 or Glut-4 (rabbit, 1:100; Abcam, UK) was added, before incubating at $4^{\circ} \mathrm{C}$ overnight. After washing, cells were blocked and incubated in Cy3-conjugated donkey anti-rabbit IgG secondary antibody (1:500; Jackson 
ImmunoResearch Inc, PA, USA) and TO-PRO-3-iodide (1:500; Invitrogen, Spain) for 45min at $37^{\circ} \mathrm{C}$. Coverslips were mounted in pre-mixed Mowiol (Calbiochem, CA, USA), glycerol, Tris-Cl and $2.5 \%$ DABCO anti-fading agent (DABCO, Denmark) on cleaned glass slides.

\begin{abstract}
Quantitative confocal analyses: For each coverslip, a minimum of six distinct and randomly chosen visual fields were photographed and analysed as z-stacks using a Leica DMIRE2 confocal microscope and software [39]. Mean intensity of $\mathrm{Cy} 3$ fluorecence indicated relative expression levels of CD-36 and Glut-4. For CD-36, any cell containing a region of at least $1 / 4$ its total area with a fluorescence intensity above the mean value for all control cells measured was considered to show increased sarcoplasmic/plasma membrane expression. For Glut-4, whose plasmatic expression is relatively more homogeneous than that of CD-36, changes in its distribution between the nucleus/nuclear membrane and cytoplasm/plasma membrane compartments were determined as previously [39]. Quantifications were carried out twice, by two independent observers, and expressed as percentages of cells with altered CD-36 or Glut-4 distribution.
\end{abstract}

\title{
$\underline{\text { Micro-array analysis }}$
}

Primary cultures $\left(4 \times 10^{5} / \mathrm{P} 6\right.$ well) were serum-deprived for $12 \mathrm{~h}$ before $3 \mathrm{~h}$ treatment with $50 \mu \mathrm{mol} / \mathrm{L}$ aliskiren. Total RNA was extracted using an RNeasy Total RNA Extraction Kit (Quiagen KK, UK) and its integrity assessed with an AGILENT 2100 Bioanalyzer and RNA Nano LabChip (Agilent Technologies, Germany). cDNA was synthesized from 300ng of total RNA using a Whole Transcript (WT) cDNA Synthesis and Amplification Kit (Affymetrix, CA, USA) and the GeneChip WT Sense Target Labeling Assay Manual protocol (Affymetrix, CA, USA). The amount of cDNA concentration was measured using a NanoDrop spectrophotometer (Thermo Scientific, Spain). Correct cDNA fragmentation was checked with the AGILENT 2100 Bioanalyzer. Expression of the complete rat genome was evaluated using rat Gene 1.0 ST microarrays (Affymetrix, CA, USA). 
A bio-informatic analysis was performed by Progenika BioPharma SA (Spain). Change values were determined as follows. 1) Quality control: array outlier analysis using the micro-array normalization software DNA-Chip Analyzer (dChip); 2) pre-processing of data using the Robust Multi-chip Average (RMA) (yielding 27,342 probe sets which after background normalization were equivalent to 13,768 sets); 3) array global normalization using the Partek Genomics Suite v7.3.1 program (Partek Inc, MO, USA); 4) second filtration of data, maintaining only sequences with expression changes, measured as standard deviation of normalized intensity data (yielding 8,521 sequences); 5) statistical analysis, principal component analysis (PCA) and hierarchical cluster analysis. To identify statistically significant changes between control and aliskiren-treated groups, a linear regression model was used $(\mathrm{Yi}=$ condition $\varepsilon$, where $\mathrm{Yi}$ is intensity of $\mathrm{Y}$ for each sequence, 'condition' is the effect of any particular treatment on intensity, and $\varepsilon$ is the nonmeasurable error). Results for individual sequences were expressed as fold-change relative to the baseline (aliskiren $v s$ control, FC). For validation by real-time PCR and western blotting, we selected the genes most closely associated with lipid metabolism and with highly significant $(p<0.001)$ and/or large fold-changes in expression; additionally we included the gene with the lowest ' $\mathrm{p}$ ' value in the array, AT-Rich Interaction Domain family member number 5a (Arid 5a, also known as Modulator Recognition Factor 1 [40]). The micro-array was analysed in terms of functional groups of genes, and genes closely related to cholesterol biosynthesis were also selected for validation.

\section{$\underline{\text { Real-time quantitative PCR }}$}

a) to validate microarray

RNA was extracted using a Qiagen RNeasy kit, following the manufacturer's instructions (Qiagen Iberia SL, Spain). For relative quantification, we performed an RT reaction with an $\mathrm{RT}^{2}$ First Strand Kit (SA Biosciences, Tebu-bio Iberia, Spain). Real-time PCR was performed using SA 
Biosciences RT² SYBR Green/ROX qPCR Master Mix (SA Biosciences, Tebu-bio Iberia, Spain) according to the manufacturer's instructions, and the following specific primers for rat: Ras-related associated with diabetes (Rrad), 191bp, PPR06499A, reference position 800-818, GenBank accession no. NM053338.1; Insulin-induced gene-1 (Insig1), 103bp, PPR42307A, reference position 557-576, GenBank accession no. NM022392.1; Lipin-1 (Lpin1), 63bp, PPR59564A, reference position 2213-2234, GenBank accession no. NM001012111.1; Pyruvate dehydrogenase kinase, isoenzyme-4 (Pdk4), 91bp, PPR48407A, reference position 1246-1268, GenBank accession no. NM053551.1; 3-hydroxy-3-methylglutaryl-Coenzyme-A synthase-1 (Hmgcs1), 66bp, PPR43438E, reference position 3138-3156, GenBank accession no. NM017268.1; Lanosterol synthase (Lss), 182bp, PPR44730A, reference position 2747-2771, GenBank accession no. NM031049.1; Farnesyl diphosphate farnesyl transferase-1 (Fdft1), 117bp, PPR43022A, reference position 1250-1268, GenBank accession no. NM019238.2; 7-dehydrocholesterol reductase (Dhcr7), 139bp, PPR42280A, reference position 1369-1387, GenBank accession no. NM022389.2; 3-hydroxy-3-methylglutaryl-Coenzyme-A reductase (Hmgcr), 93bp, PPR44338A, reference position=2595-2614, GenBank accession no. NM013134.2; AT-Rich Interaction Domain family member number 5a (Arid5A), 172bp, PPR46170A, reference position 554, GenBank accession no. NM001034934.1.

\section{b) to identify $(P) R$ and Igf/M6P2 receptors}

Real-time PCR for the identification of (P)R and Igf2/M6P receptors was performed using a Stratagene Brilliant® II SYBR® Green QRT-PCR Master Mix Kit (Stratagene, CA, USA) following the manufacter's instructions and the following specific primers (TIB Molbiol, Germany): for mouse: (P)Rr, 172bp, GenBank accession no. NM027439.4, Forward primer: CCCAGCGAGGAGAGAGTGTATATG, Reverse primer: CGGAGAGAAAGAGCAGGTCAAC; Igf2/M6Pr, 198bp, GenBank accession no. NM010515, Forward primer: 
rat: (P)Rr, 109bp, GenBank accession no. XM217592.5, Forward primer:

GGTCTGACTGCGGTGCTC, Reverse primer: AGAGAAGAGAGGAGAACGACAAG; Igf2/M6Pr, 154bp, GenBank accession no. NM012756.1, Forward primer: GCCACGAGACTGCTGACTG, Reverse primer: AGGAGGAGACTGAGGACTGC. PCR products were separated by electrophoresis on a $2 \%$ agarose gel and stained with ethidium bromide for UV visualization. Results of comparative real-time PCRs were analyzed using MxPro v.4 software (Stratagene, Spain).

\section{$\underline{\text { Immunoblotting }}$}

Serum-deprived primary cultures of neonatal-rat cardiomyocytes $\left(4 \times 10^{5} / \mathrm{P} 6\right.$ well) were treated with $50 \mu \mathrm{mol} / \mathrm{L}$ aliskiren for 3-6h or 2-30min (for ERK1/2 phosphorylation) and/or with $0.01 \mu \mathrm{M}$ recombinant human (Anaspec, Inc. San José, CA, USA) or rat (Anaspec Inc. San José, CA, USA) renin for $5 \mathrm{~min}$. Cells were then lysed with Triton X-100 (1\% buffered in 50mmol/L Tris- $\mathrm{HCl}$, $150 \mathrm{mmol} / \mathrm{L} \mathrm{NaCl}, 5 \mathrm{mmol} / \mathrm{L}$ EDTA, $1 \mathrm{mmol} / \mathrm{L}$ phenylmethylsulphonylfluoride, $10 \mu \mathrm{g} / \mathrm{ml}$ leupeptin, $10 \mu \mathrm{g} / \mathrm{ml}$ aprotinin, $10 \mu \mathrm{g} / \mathrm{ml}$ trypsin inhibitor and $1 \mathrm{mmol} / \mathrm{L} \mathrm{NaVO}_{4}$ ). Samples were subjected to SDS-PAGE under denaturing conditions on $10 \%$ gels and electroblotted onto PVDF membranes (Amersham Pharmacia Biotech, Germany). Membranes were treated with the following primary antibodies at $4^{\circ} \mathrm{C}$ overnight: anti-Rrad, anti-Hmgcs1, anti-Insig1, anti-Lpin1, anti-Pdk4 (1:200; Santa Cruz Biotechnology, CA, USA), Hmgcr (1:500; Upstate Biotechnology, Millipore Corporate, MA, USA), anti-Fdft1 (1:200), anti-Lss (1:1000) (Abcam, MA, USA), anti-Dhcr7 (1:750; Abnova, Tebu-bio Iberia, Spain), anti-phospho-Erk1/2 and anti- Erk1/2 (1:1000; Cell Signaling Technology, New England BioLabs, UK). Membranes were then incubated with horeseradish-preoxidase-conjugated secondary antibody (1:2000; Santa Cruz Biotechnology, CA, USA) followed by chemiluminescence detection (Millipore Corporate, MA, USA). Anti- $\beta$-actin (1:1000; Santa Cruz Biotechnology, CA, USA) was used as a loading control. Densitometric 
analyses were performed using a UVP EC3 Imaging System (Ultra-Violet Products Ltd, UK) and

\section{$\underline{\text { Statistical and gene network analyses }}$}

Statistical data are from at least three independent experiments $(\mathrm{n}=3)$ and expressed as mean $\pm \mathrm{SD}$ or as mean \pm SEM (for confocal microscopy analysis). Statistical significance of the differences between experimental values was determined using Mann-Whitney U, t-tests, Fisher's exact test or ANOVA as appropriate ( $\mathrm{p}<0.05$ considered significant). For the microarray, in addition to the statistical analyses of individual genes, functional groups of genes were compared, using the following databases: IPA (IPA ${ }^{\circledR} 8.8$; Ingenuity Systems Inc., Redwood City, CA; www.ingenuity.com), Gene Ontology (www.geneontology.org), Kyoto Encyclopedia of Genes and Genomes (KEGG) metabolic pathways (www.genome.jp/kegg/), Obesity Gene Map Database (www.obesitygene.pbrc.edu) and Database for Annotation, Visualization and Integrated Discovery (DAVID, National Institute of Allergy and Infectious Diseases (NIAID, USA)).

In the IPA system, gene expression changes are considered in the context of physical, transcriptional, or enzymatic interactions of the gene/gene products and are grouped according to interacting gene networks. The score assigned to any given gene network takes into account the total number of molecules in the data set, the size of the network, and the number of 'networkeligible' genes/molecules in the data set. The network score is based on the hypergeometric distribution and is calculated with the right-tailed Fisher's exact test. The network score is the negative log of that ' $\mathrm{p}^{\prime}$ value.

\section{Results}

Aliskiren treatment did not affect cardiomyocyte viability or the cell cycle. 
Aliskiren $(1 \mathrm{nmol} / \mathrm{L}-50 \mu \mathrm{mol} / \mathrm{L})$ treatment for $24 \mathrm{~h}$ or $48 \mathrm{~h}$ did not alter the viability of, or cell-cycle, assayed respectively by MTT and flow cytometry assays in HL-1 cardiomyocytes (Fig. 1), or primary cultures of neonatal rat cardiomyocytes (data not shown).

$\underline{\text { Aliskiren increased dodecanoic-acid uptake and plasma membrane localization of the fatty-acid }}$ transporter CD-36, but decreased cytoplasm/plasma membrane:nuclear distribution of the glucose $\underline{\text { transporter Glut-4. }}$

Flow cytometry showed that aliskiren induced uptake of the MCFA dodecanoic-acid after 30min in HL-1 cardiomyocytes (Fig. 1C.1), and after 120min in primary cultures of neonatal-rat cardiomyocytes (Fig. 1C.2). Immunocytochemistry and confocal analyses (Fig. 2) showed that aliskiren also increased plasma membrane localization of the fatty-acid transporter CD-36, in primary-cultured adult-human (Fig 2A-I) and neonatal-rat (Fig. 2J-O) cardiomyocytes after 30min. Interestingly, aliskiren caused a complementary decrease in the localization of the glucose transporter Glut-4 in the cytoplasm/plasma membrane compartment at 30min (Fig. 2P-U). These changes were aliskiren-dose-dependent (Table 1), and not significant at $15 \mathrm{~min}$ (data not shown). It should be noted that the changes we observed in MCFA uptake and intracellular redistribution of Glut-4 and CD-36 transporters after treatment with aliskiren were obtained with doses of $10 \mu \mathrm{M}$ (see Figures 1 and 2, and Table 1), and that previous studies have shown that concentrations of aliskiren in the low- $\mu \mathrm{M}$ range are present in the blood during treatment with aliskiren [41]. This range of doses has also been used in several other recent studies on the effects of aliskiren at the cellular level $[8,37,38,41]$.

\begin{abstract}
$\underline{\text { Aliskiren induced intracellular phosphorylation of ERK1/2 in a dose- and time-dependent manner }}$ which was unaffected by renin treatment, and did not involve changes in expression levels of $(\mathrm{P}) \mathrm{R}$ or Igf2/M6P receptors.
\end{abstract}


Immunoblotting showed that aliskiren induced intracellular phosphorylation of ERK1/2 in HL-1, neonatal-rat and adult-human cardiomyocytes. Experiments with primary-cultured neonatal-rat (Fig. 3A, B, C.2, D, E) showed that ERK1/2 phosphorylation was dose- and time- dependent. Using the optimal dose $(50 \mu \mathrm{mol} / \mathrm{L})$ and time $(5 \mathrm{~min})$ ascertained in the rat primary cultures, a significant response was also seen in primary-cultured adult-human cardiomyocytes (Fig. 3C.1). ERK1/2 phosphorylation was not affected by renin treatment (F.1, F.2). HL-1 cells showed similar time- and dose-dependent ERK1/2 phosphorylation responses to aliskiren (Fig. 3: G.1, G.2). Realtime qPCR experiments following $50 \mu \mathrm{mol} / \mathrm{L}$ aliskiren treatments for $3 \mathrm{~h}$ did not induce changes in mRNA expression levels of $(\mathrm{P}) \mathrm{R}$ or Igf2/M6P receptors in either neonatal-rat or HL-1 cardiomyocytes (data not shown).

\section{$\underline{\text { Microarray Analysis }}$}

Bio-informatic analysis of the results of the microarray showed that 652 gene sequences were significantly modified by a $3 \mathrm{~h}$ treatment with $50 \mu \mathrm{mol} / \mathrm{L}$ aliskiren in primary-cultured neonatal-rat cardiomyocytes. We explored the functional interactions among the altered genes using IPA (Ingenuity Pathway Analysis), as previously described [42,43], and which is integrated with several other databases such as KEGG Metabolic Pathways, and the Gene Ontology and Obesity Gene Map Database. A summary of the global results of the microarray obtained using Gene Ontology and IPA databases is shown in Figure 4.A. Functional analysis of the entire data set using IPA and restrictions set to 'biological/cellular functions related to cardiovascular system cells' (with a cut-off of $\mathrm{p}<0.001$ ) and 'cardiovascular function' (with a cut-off of $\mathrm{p}<0.05$ ) identified biological functions and cardiac alterations that were most statistically significant (Table 2). Righttailed Fisher's exact test was used to calculate $p$ values which indicated the probability that each biological function and/or disease assigned to the data set was not due to chance alone. Functional classification of differentially expressed genes revealed a cluster of genes involved in lipid metabolism as the altered biological function with the lowest $\mathrm{p}$ value $\left(\mathrm{p}<10^{-4}\right.$; Table 2$)$. We next 
explored the functional interactions among the altered genes using IPA. IPA identified a gene interactive network containing all the genes related to lipid and/or fatty-acid metabolism that we had found to be altered by treatment of cardiomyocytes with aliskiren (Fig.4. B).

\section{Aliskiren up-regulated several enzymes of key importance to lipid metabolism and cholesterol biosynthesis in neonatal-rat and adult-human cardiomyocytes.}

For confirmation analyses we chose the three up-regulated genes implicated in lipid and/or fattyacid metabolism that showed the lowest $\mathrm{p}$ values ( $\mathrm{p}<0.001)$ : Insig1 (1.60 FC), Lpin1 (1.46 FC) and Pdk4 (1.80 FC) and were also included in the most statistically significant network resulting from the IPA analysis (lipid metabolism; score=15). We also added two more genes to our confirmation analyses, namely Rrad, whose expression was diminished by aliskiren $(\mathrm{p}<0.001)$ with the greatest FC after $3 \mathrm{~h}$ aliskiren treatment (-2.46 FC) and which is involved in cardiomyocyte contractility, viability and glucose metabolism [44-46], and Arid 5a, whose expression was also diminished by aliskiren treatment $(-2.16 \mathrm{FC})$ with the lowest $\mathrm{p}$ value in the whole array $\left(\mathrm{p}=7.38 \times 10^{-5}\right)$.

Real-time qPCR and immunoblotting confirmed the microarray analysis, not only for all the enzymes assayed in neonatal-rat primary cardiomyocytes, but for selected enzymes in adult-human primary cardiomyocytes. Thus, in neonatal-rat and adult-human cardiomyocytes treated with $50 \mu \mathrm{mol} / \mathrm{L}$ aliskiren, after $3 \mathrm{~h}$ mRNA expression, and after $6 \mathrm{~h}$ protein expression were increased for Insig1, Lpin1 and Pdk4 (involved in lipid metabolism); by contrast, mRNA and protein expression of Rrad (involved in glucose metabolism) and mRNA of Arid 5a were decreased (Fig. 5). Arid 5a protein expression was not analyzed due to the lack of a good quality commercially available antibody.

Analysis of the microarray in terms of functional groups of genes revealed that the cholesterol biosynthesis pathway was markedly altered after $3 \mathrm{~h}$ of aliskiren treatment in neonatal-rat 
cardiomyocytes. In fact, the steroid biosynthesis pathway was selected by KEGG Metabolic Pathways with $\mathrm{p}=10^{-6}$ and by IPA with $\mathrm{p}<10^{-4}$. The following genes belonging to the cholesterol metabolic pathway were therefore also selected from the microarray statistical analysis for further confirmation by real-time PCR and immunoblotting: Hmgcs1 (1.43 FC, p<0.001), Hmgcr (1.31 FC, $\mathrm{p}<0.01)$, Fdft1 (1.22 FC, p<0.05) Lss (1.19 FC, p<0.05), and Dhcr7 (1.56 FC, $\mathrm{p}<0.01)$. It should be noted that all the cholesterol-synthetic genes were also present in the lipid-metabolism network generated by IPA with the highest significance score in the analysis of the whole array (Fig.4.B). Real-time PCR and immunoblotting showed that expression of all these enzymes involved in cholesterol biosynthesis were significantly increased at both RNA and protein levels at 3h (Fig. 6).

\section{Discussion}

Our principal finding is that in cardiomyocytes from rodent and human sources, aliskiren can significantly increase uptake of the MCFA dodecanoic acid and modify intra-cellular distribution of fatty-acid (CD-36) and glucose (Glut-4) transporters, as well as up-regulate key lipid- and glucose-handling enzymes. Additionally, we found that aliskiren up-regulated enzymes along the entire length of the cholesterol biosynthesis pathway, and that all of these were common to a lipid metabolism gene network generated from our results.

Whilst our study appears to be the first to investigate directly a relationship between RAAS inhibition and lipid or cholesterol metabolism in cardiomyocytes, activation of RAAS has previously been implicated in lipid metabolism. Thus, mice lacking angiotensinogen have reduced plasma levels of triglycerides and cholesterol which are associated with decreased fatty-acidsynthase activity in epididymal fat [47]. Several studies have suggested that local adipose-tissue effects of RAAS are important in lipid metabolism [48], while it has been shown that mice with an 
ACE-gene deletion have less body fat and increased energy expenditure than their normal littermates [49]. Type-2 diabetic mice treated with aliskiren also have substantially decreased body fat [18] and, moreover, direct renin inhibition by aliskiren can reduce body-weight gain, adiposity and plasma leptin levels in diet-induced obesity in mice [50]. RAAS activation in renal tissue has also recently been linked to lipid disorders and fat accumulation in rodents [51].

At the cellular level, evidence from cultured adipocytes suggests that angiotensin II can directly inhibit lipolysis while increasing fatty-acid-synthase activity [52]. On the other hand, a recent study [31] has shown that rats over-expressing the human renin gene develop obesity and glucose intolerance, but that these metabolic changes are not related to angiotensin II. This raises the intriguing possibility of a new but as-yet unknown substrate for renin - other than angiotensinogen - which could have an important role in energy homeostasis. Therefore, the increases in MCFA cardiomyocyte uptake and expression of genes involved in subsequent intracellular lipid processing that we have observed in the presence of the DRI aliskiren might be attributable either to inhibition of RAAS, or to alterations involving a hypothetical new substrate

We have found that aliskiren modifies the expression of several enzymes closely related to lipid metabolism, and these observations are closely correlated with our functional data showing that aliskiren induces fatty-acid uptake and CD-36 and Glut-4 re-distribution in cultured cardiomyocytes. Glut-4 and CD-36 dynamically traffic between subcellular compartments and the plasma membrane in cardiomyocytes, increasing uptake of glucose and fatty acids, respectively [53]. Our results therefore strongly suggest that CD-36 (and potentially other) fatty-acid transporters execute the functional effect of aliskiren on increasing fatty-acid uptake that we observed. In the healthy adult heart, the balance between fatty-acid and carbohydrate metabolism is tightly controlled and optimises energy production [54]. We have focused our study on the concept that an anti-hypertensive drug such as aliskiren, a direct renin inhibitor that acts through the 
inhibition of renin-angiotensin system, can also affect other key physiological processes (in this case nutrient metabolism) in a cell-type as highly differentiated as a cardiomyocyte. Regulation of fatty-acid transport across the cardiomyocyte plasma membrane is essential to cardiovascular health, and dysregulation can result in myocardial lipotoxicity [55]. In normal cardiac metabolism, intracellular fatty-acid levels are thought to be maintained at low levels and thus provide the driving force for transport into the cell [55]. In order to ascertain whether our observed increase in fatty-acid uptake induced by aliskiren is beneficial or harmful, further experiments to measure intracellular fatty-acid levels and rates of fatty-acid oxidation in aliskiren-treated cardiomyocytes are required..

We found that expression of the intracellular enzyme Rrad, a small GTP-ase required for excitation-contraction coupling and $\beta$-adrenergic signalling in the heart [44], was diminished by aliskiren in cardiomyocytes. cGMP signaling is a cardinal regulator of the relative activities of $\beta$ oxidation (energy production) and esterification to triglycerides (for storage) of fatty acids, also critical to cardiac homeostasis [54]. Rrad is over-expressed in skeletal muscle of patients with type2 diabetes mellitus and/or obesity, and its over-expression has been associated with a decrease in insulin-stimulated glucose uptake in cultured muscle and fat cells [56], as well as with alterations in lipid metabolism characteristic of type-2 diabetes in vivo [57]. Therefore, our observed decrease in expression of Rrad due to aliskiren makes sense, both in relation to previous studies and to the aliskiren-induced increase in fatty-acid uptake that we have observed in cultured cardiomyocytes. Whilst there do not appear to have been any previous investigations focussing on the effects of Rrad on cardiac metabolism, it has been shown that enhanced cGMP signalling promotes triglyceride synthesis in cardiomyocytes [54]. Our results with Pdk4 agree with those of Zhao et al [58], in which mice selectively over-expressing Pdk4 in the heart showed increased fatty-acid and decreased glucose oxidation. Reduced Pdk4 expression has also been associated with an increase in glucose:fatty acid oxidation [59]. 
Up-regulation of Insig1, a feedback mediator of fatty-acid and cholesterol synthesis [60], has previously been found to be anti-adipogenic [61,62], while Insig1-knock-out mice have raised liver cholesterol and triglycerides [63], and Insig1 gene variants are associated with coronary heart disease in humans [64]. Our results with Lpin1 could be favourable to cardiomyocyte lipid homeostasis, as it has been suggested that down-regulation of Lpin1, seen in obesity-related insulin resistance [65], in failing myocardium of type-2 diabetic rats, and in atrial tissue of type-2 diabetic patients [66], can contribute to a worsened metabolic profile [65]. In the confirmation studies was included the gene with the second highest change in expression (-2.16 FC) and the lowest ' $\mathrm{p}$ ' value of the micro-array, Arid 5a, a member of the AT-Rich Interaction Domain family whose proteins are characterized by their ability to bind preferentially to AT-rich DNA sequences and have roles in regulating growth, differentiation, development and, interestingly, triglyceride metabolism $[40,67]$. Intriguingly, Arid5a is abundantly expressed in the human heart, where it acts as a corepressor for oestrogen receptor-alpha [40]. Given the complex actions exerted by oestrogens on the cardiovascular system, our expression data merit further investigation.

\begin{abstract}
Alterations in the cellular content or intracellular localization of proteins involved in fatty-acid uptake and transport can compromise cardiac function [68]. Conversely, cardiac diseases may lead to alterations in the expression and/or localization of these fatty acid-handling proteins [68]. Further studies to elucidate the precise relationships between aliskiren-induced changes in proteins involved in lipid metabolism and transport, and cardiac function under normal and pathological conditions should therefore lead to new therapeutical strategies in the use of this drug. For these reasons, we believe that the results of our study can serve as a useful starting point for the interpretation and integration of the many potential intracellular responses that may be triggered by aliskiren, a DRI previously considered to have only specific anti-hypertensive effects mediated by inhibition of the renin-angiotensin system. Whether the additional effects of aliskiren that we have
\end{abstract}


described are also mediated by RAAS inhibition, or by other as-yet un-characterised mechanisms, it is evident that this drug can regulate functions in cardiomyocytes (and potentially in other cell types) as fundamental as lipid metabolism.

While the up-regulation by aliskiren of cholesterol-biosynthetic enzymes that we observed also merits further investigation, it should be noted that we did not find changes in expression levels of any genes known to be abnormally re-expressed in hypertrophied cardiomyocytes (smooth muscle $\alpha$-actin, atrial natiuretic peptide, or $\beta$-myosin heavy chain). In hypertensive patients, moreover, monotherapy with aliskiren appears to have generally beneficial effects, with respect to cholesterol metabolism and stabilising atherosclerotic plaques more completely, than with ACE inhibitors or ARBs $[69,70]$. We can not at present say whether the up-regulation in the cholesterol biosynthetic pathway observed at the cardiac level is harmful or beneficial, as the number of relevant published studies is currently too small. In apparently the only other cardiomyocyte-level study to date to describe cholesterol metabolism [71], induction of the cholesterol pathway caused a dramatic increase in farnesylated and membrane-associated Ras, which has been shown to regulate proteins that control signal transduction and excitability - in particular to increase parasympathetic:sympathetic response [71]. Additionally, in rat ventricular cardiomyocytes, cholesterol regulates L-type $\mathrm{Ca}^{2+}$ channel function [72], which is fundamental to excitationcontraction coupling [72]. As shown in the network in Fig. 4, the cholesterol biosynthetic and lipid-metabolism-related enzymes modified by aliskiren in cardiomyocytes are closely related. Additional research will, however, be necessary to elucidate how the upregulation of cholesterol biosynthesis is integrated with the control of lipid anabolism and/or catabolism in this cell type.

The major analysis in the current study has been centred on the changes in fatty-acid/lipid metabolism that we found to be induced by aliskiren in cultured cardiomyocytes. Some other interesting data, however, were also found in the functional analysis of the micro-array carried out 
using IPA (Table 2). Notably, IPA identified aliskiren-induced alterations in the expression of genes whose protein products are known to be involved in physiopathological processes leading to several cardiovascular diseases. One example was the down-regulation by aliskiren of ERK1/2 dual-specificity phosphatase 6 (Dusp 6; FC -1.32, p<0.01) whose over-expression has been associated with induction of heart failure in experimental animals [73]; another example was a decrease in gene expression $(\mathrm{FC}-1.33 ; \mathrm{p}<0.001)$ of connective tissue growth factor $(\mathrm{Ctgf}$, the main orchestrator of activity of important local factors that can evoke cardiac fibrosis [74]). These results clearly also merit further investigation.

Cardiomyocytes, including from the same sources as in our study [75,76], possess all the components of an operative intracellular RAAS, and bind (pro)renin to cell-surface (P)R [28] and Igf2/M6P [77] receptors. Activation of (P)Rr induces intracellular signalling by at least two pathways, one leading to angiotensin-II production which is inhibited by aliskiren [1,3], and another which is angiotensin-II-independent, as shown by its not being inhibited by aliskiren [2931]. Igf2/M6P [77] receptor activation does not lead to angiotensin generation [35]. Since it has been suggested that renin/prorenin signalling can have cardiac effects independent of angiotensin II production [29], our aim was to determine whether in cardiomyocytes aliskiren could affect: a) expression levels of the receptors that bind renin and prorenin in cardiomyocytes, and b) intracellular signalling downstream of $(\mathrm{P}) \mathrm{Rr}$, specifically, ERK1/2 phosphorylation, a critical downstream effector of renin-(P)Rr [28] binding. Our aliskiren treatments did not alter mRNA expression levels of (P)Rr or Igf2/M6Pr, but in an initial series of experiments and in agreement with Saris et al (2006) [29] we confirmed that in the cardiomyocytes we were using renin treatment did not affect ERK1/2 phosphorylation (data not shown). Intriguingly, aliskiren alone was able to induce ERK1/2 phosphorylation in our cardiomyocytes, suggesting that $\mathrm{P}(\mathrm{R}) \mathrm{r}$ could have been activated but not up-regulated. By comparison, in the in vivo kidney, but not in renal cell types in vitro [30,38], (P)Rr mRNA is down-regulated in response to aliskiren [38]; in human podocytes 
(P)Rr levels are unchanged whilst those of ERK1/2 are decreased in response to aliskiren [8].

Increases in $(\mathrm{P}) \mathrm{Rr}$ expression occur in diabetes and as a response to high glucose [78], and have also been linked to hypertension and increased heart-rate in rats [79].

Whilst the mechanism by which aliskiren phosphorylated ERK1/2 in our study is therefore not certain, we carried out experiments with aliskiren both in the presence and absence of exogenous renin, but found no difference in effect (Fig. 3, and additional data not shown). One possible explanation is that renin was produced by the cardiomyocytes but remained within the cytoplasm [80], where it interacted with aliskiren. Notably, Ras is an upstream regulator of ERK1/2 phosphorylation, and is itself up-regulated by the cholesterol pathway [71]. Thus, aliskiren could have induced activation of ERK 1/2 and the metabolic changes that we describe as a consequence of cell-surface $(\mathrm{P}) \mathrm{Rr}$, intracellular (pro)renin, or by means of an as-yet unidentified, non-RAASblockade mechanism [8]. The specific mechanism of action of aliskiren should therefore be the subject of subsequent work. Finally, we can not at present clearly define the effects of our observed increase in phosphorylation of ERK1/2 induced by aliskiren in cardiomyocytes. The potentially harmful effects of an increase in renin caused paradoxically during renin inhibition have caused much debate [81]. In our cardiomyocytes, aliskiren did not decrease expression of (P)Rr or Igf2/M6Pr receptors, so the angiotensin II-independent effects of a potential renin increase at the cardiac level should perhaps be further considered in relation to clinical treatment. It has also recently been demonstrated that the ERK1/2 pathway activation is involved in regulating cardiac fatty-acid metabolism [82] and in the contraction-induced increase in plasma-membrane CD-36 and fatty-acid uptake in rodent myocytes [83]. These latter findings could constitute a nexus between our functional data showing that aliskiren stimulates fatty-acid uptake and increases ERK1/2 phosphorylation. However, we can not at present determine whether ERK1/2 phosphorylation is required for the increase in fatty-acid uptake and changes in CD-36 and Glut-4 localization we found to be induced by aliskiren in cardiomyocytes. 
In conclusion, in cultured rodent and human cardiomyocytes aliskiren has important regulatory actions on several key areas of metabolism. Some of the mechanisms by which these actions occur remain unclear, which highlights the increasing complexity of RAAS and especially the cellular function of $(\mathrm{P}) \operatorname{Rr}[20]$. Our study therefore raises fundamental questions for an emerging area of investigation into the metabolic effects of aliskiren and their relationship with organ protection and excitation-contraction coupling. The main limitation of our study was not being able to positively identify the mechanisms of action for the metabolic effects of aliskiren that we report and, specifically, whether these effects are mediated by RAAS or non-RAAS components. Another limitation was that we could not repeat all our experiments in human cardiomyocytes. Further investigations in rodent and human cardiomyocytes should therefore establish whether angiotensin I and/or angiotensin II are involved, and whether $(\mathrm{P}) \mathrm{Rr}$ is activated without being up-regulated, in the metabolic effects of aliskiren. As it is already known that RAAS affects lipid metabolism in non-cardiomyocyte cell-types [18,48-52], studying the mechanisms of aliskiren on other cell types might indicate components of its mechanism of action that are also possessed by cardiomyocytes. Finally, it will be fundamentally important to link the metabolic mechanisms of action of aliskiren with excitation-contraction coupling in cardiomyocytes from several sources.

\section{Funding}

This work was supported by a grant to FL and JRG-J from Novartis SA, Spain, via the Spanish Society of Cardiology (SEC), and by the Health Research Fund of Instituto de Salud Carlos III (FIS08/0044). FL is funded by the Health Research Fund of Instituto de Salud Carlos III (FIS) and Xunta de Galicia (SERGAS). PL is funded by Red Temática de Investigación Cooperativa (REDINSCOR). 


\section{Acknowledgements \\ We thank Marta Picado Barreiro and Manuel Calaza Cabanas for expert assistance, and Peter Rothwell for critically reading an earlier version of the manuscript.}

\section{Potential conflict of interest}

See Funding from Novartis SA, Spain (above).

\section{References}

[1] Nussberger J, Wuerzner G, Jensen C, Brunner HR. Angiotensin II suppression in humans by the orally active renin inhibitor Aliskiren (SPP100): comparison with enalapril. Hypertension 2002;39:E1-E8.

[2] Pimenta E, Oparil S. Role of aliskiren in cardio-renal protection and use in hypertensives with multiple risk factors. Ther Clin Risk Manag 2009;5:459-64.

[3] Israili ZH, Velasco M, Bermúdez V. Direct renin inhibitors as antihypertensive agents. Am J Ther 2010;17:237-54.

[4] Hollenberg NK. Direct renin inhibition and the kidney. Nat Rev Nephrol 2010;6:49-55.

[5] Stanton AV, Gradman AH, Schmieder RE, Nussberger J, Sarangapani R, Prescott MF.

Aliskiren monotherapy does not cause paradoxical blood pressure rises: meta-analysis of data from 8 clinical trials. Hypertension 2010;55:54-60. 
[6] Krone W, Hanefield M, Meyer H-F, Jung T, Bartlett M, Yeh C-M, et al. Comparative efficacy and safety of aliskiren and irbesartan in patients with hypertension and metabolic syndrome. J Hum Hypertens 2010;doi:10.1038/jhh.2010.38 (in press).

[7] van Esch JH, Moltzer E, van Veghel R, Garrelds IM, Leijten F, Bouhuizen AM, et al. Beneficial cardiac effects of the renin inhibitor aliskiren in spontaneously hypertensive rats. J Hypertens 2010; 28:2145-55.

[8] Sakoda M, Ichihara A, Kurauchi-Miho A, Narita T, Kinouchi K, Murohashi-Bokuda K, et al. Aliskiren inhibits intracellular angiotensin II levels without affecting (pro)renin receptor signals in human podocytes. Am J Hypertens 2010;23:575-80.

[9] Singh VP, Le B, Khode R, Baker KM, Kumar R. Intracellular angiotensin II production in diabetic rats is correlated with cardiomyocyte apoptosis, oxidative stress, and cardiac fibrosis. Diabetes 2008;57:3297-306.

[10] Paulis L, Unger T. Novel therapeutic targets for hypertension. Nat Rev Cardiol 2010;7:43141.

[11] Braga MF, Leiter LA. Role of renin-angiotensin system blockade in patients with diabetes mellitus. Am J Cardiol 2009;104:835-9.

[12] Epstein BJ, Smith SM, Choksi R. Recent changes in the landscape of combination RAS blockade. Expert Rev Cardiovasc Ther 2009;7:1373-84. 
[13] Loriga G. Direct Renin inhibition: promising treatment in renoprotection? Recent Pat Cardiovasc Drug Discov 2010;5:113-9.

[14] Mende CW. Application of direct renin inhibition to chronic kidney disease. Cardiovasc Drugs Ther 2010;24:139-49.

[15] Feldman DL. New insights into the renoprotective actions of the renin inhibitor aliskiren in experimental renal disease. Hypertens Res 2010;33:279-87.

[16] Pöss J, Werner C, Lorenz D, Gensch C, Böhm M, Laufs U. The renin inhibitor aliskiren upregulates pro-angiogenic cells and reduces atherogenesis in mice. Basic Res Cardiol 2010; 105:725-35

[17] Dong YF, Liu L, Kataoka K, Nakamura T, Fukuda M, Tokutomi Y, et al. Aliskiren prevents cardiovascular complications and pancreatic injury in a mouse model of obesity and type 2 diabetes. Diabetologia 2010;53:180-91.

[18] Iwai M, Kanno H, Tomono Y, Inaba S, Senba I, Furuno M, et al. Direct renin inhibition improved insulin resistance and adipose tissue dysfunction in type 2 diabetic KK-A(y) mice. $\mathbf{J}$ Hypertens 2010;28:1471-81.

[19] Stegbauer J, Lee DH, Seubert S, Ellrichmann G, Manzel A, Kvakan H, et al. Role of the renin-angiotensin system in autoimmune inflammation of the central nervous system. PNAS USA 2009;106:14942-7. 
[20] Funke-Kaiser H, Zollmann FS, Schefe JH, Unger T. Signal transduction of the (pro)renin receptor as a novel therapeutic target for preventing end-organ damage. Hypertens Res 2010;33:98-104.

[21] Splenser AE, Fisher ND, Danser AH, Hollenberg NK. Renal plasma flow: glomerular filtration rate relationships in man during direct renin inhibition with aliskiren. J Am Soc Hypertens 2009;3:315-20.

[22] Neuberg GW, Kukin ML, Penn J, Medina N, Yushak M, Packer M. Hemodynamic effects of renin inhibition by enalkiren in chronic congestive heart failure. Am J Cardiol 1991;67:63-6.

[23] Kelly DJ, Zhang Y, Moe G, Naik G, Gilbert RE. Aliskiren, a novel renin inhibitor, is renoprotective in a model of advanced diabetic nephropathy in rats. Diabetologia 2007;50:23982404.

[24] Ogawa S, Nako K, Okamura M, Senda M, Mori T, Ito S. Aliskiren reduces albuminuria and oxidative stress, and elevates glomerular filtration in japanese patients with advanced diabetic nephropathy. Hypertens Res 2010; doi:10.1038/hr.2010.250 (in press).

[25] Fogari R, Zoppi A, Mugellini A, Derosa G. Different effects of aliskiren and losartan on fibrinolysis and insulin sensitivity in hypertensive patients with metabolic syndrome. Horm Metab Res 2010; 42:892-6.

[26] Dobrin JS, Lebeche D. Diabetic cardiomyopathy: signaling defects and therapeutic approaches. Expert Rev Cardiovasc Ther 2010;8:373-91. 
[27] Mancia G, Bombelli M, Facchetti R, Casati A, Ronchi I, Quarti-Trevano F, et al. Impact of different definitions of the metabolic syndrome on the prevalence of organ damage, cardiometabolic risk and cardiovascular events. J Hypertens 2010;28:999-1006.

[28] Nguyen G, Delarue F, Burcklé C, Bouzhir L, Giller T, Sraer JD. Pivotal role of the renin/prorenin receptor in angiotensin II production and cellular responses to renin. J Clin Invest 2002;109:1417-27.

[29] Saris JJ, 't Hoen PAC, Garrelds IM, Dekkers DH, den Dunnen JT, Lamers JM, et al. Prorenin induces intracellular signaling in cardiomyocytes independently of angiotensin II. Hypertension 2006;48:564-71.

[30] Schefe JH, Neumann C, Goebel M, Danser J, Kirsch S, Gust R, et al. Prorenin engages the (pro)renin receptor like renin and both ligand activities are unopposed by aliskiren. J Hypertens 2008;26:1787-94.

[31] Gratze P, Boschmann M, Dechend R, Qadri F, Malchow J, Graeske S, et al. Energy metabolism in human renin-gene transgenic rats. Does renin contribute to obesity? Hypertension 2009;53:516-23.

[32] Dong YF, Liu L, Lai ZF, Yamamoto E, Kataoka K, Nakamura T, et al. Aliskiren enhances protective effects of valsartan against type 2 diabetic nephropathy in mice. J Hypertens 2010;28:1554-65. 
[33] Rashikh A, Najmi AK, Akhtar M, Mahmood D, Pillai KK, Ahmad SJ. Protective effects of aliskiren in doxorubicin-induced acute cardiomyopathy in rats. Hum Exp Toxicol 2010;doi:10.1177/0960327110369819 (in press).

[34] Abassi Z, Winaver J, Feuerstein GZ. The biochemical pharmacology of renin inhibitors :implications for translational medicine in hypertension, diabetic nephropathy and heart failure :expectations and reality. Biochem Pharmacol 2009;78:933-40.

[35] Saris JJ, van den Eijnden MM, Lamers JM, Saxena PR, Schalekamp MA, Danser AH. Prorenin-induced myocyte proliferation: no role for intracellular angiotensin II. Hypertension 2002;39:573-7.

[36] González-Juanatey JR, Iglesias MJ, Alcaide C, Piñeiro R, Lago F. Doxazosin induces apoptosis in cardiomyocytes by a mechanism that is independent of alpha1-adrenergic blockade. Circulation 2003;107:127-31.

[37] Feldt S, Batenburg WW, Mazak I, Maschke U, Wellner M, Kvakan H, et al. Prorenin and renin-induced extracellular signal-regulated kinase $1 / 2$ activation in monocytes is not blocked by aliskiren or the handle-region peptide. Hypertension 2008;51:682-8.

[38] Feldman DL, Jin L, Contrepas A, Zhou Y, Webb RL, Mueller DN, et al. Effects of aliskiren on blood pressure, albuminuria, and (Pro)renin receptor expression in diabetic TG(mRen-2)27 rats. Hypertension. 2008;52:130-6. 
[39] Lear PV, Iglesias MJ, Feijóo-Bandín S, Rodríguez-Penas D, Mosquera-Leal A, García-Rúa V et al. Des-acyl ghrelin has specific binding sites and different metabolic effects from ghrelin in cardiomyocytes. Endocrinology 2010;151:3286-98.

[40] Georgescu SP, Li JH, Karas RH, Brown M, Mendelsohn ME. Modulator Recognition Factor 1, an AT-rich interaction domain family member, is a novel corepressor for estrogen receptor alpha. Mol Endocrinol 2005;19:2491-501.

[41] Batenburg WW, de Bruin RJA, van Gool JMG, Müller DN, Bader M, Nguyen G, et al. Aliskiren-binding increases the half life of renin and prorenin in rat aortic vascular smooth muscle cells. Arterioscler Thromb Vasc Biol 2008;28:1151-7.

[42] Saban MR, O’Donnell MA, Hurst RE, Wu XR, Simpson C, Dozmorov I, et al. Molecular networks discriminating mouse bladder responses to intravesical bacillus Calmette-Guerin (BCG), LPS, and TNF-alpha. BMC Immunol 2008;9:4.

[43] Chen Y, Pat B, Zheng J, Cain L, Powell P, Shi K, et al. Tumor necrosis factor-alpha produced in cardiomyocytes mediates a predominant myocardial inflammatory response to stretch in early volume overload. J Mol Cell Cardiol 2010;49:70-8.

[44] Wang G, Zhu X, XieW, Han P, Li K, Sun Z, et al. Rad as a novel regulator of excitationcontraction coupling and $\beta$-adrenergic signalling in heart. Circ Res 2010;106:317-27.

[45] Chang L, Zhang J, Tseng YH, Xie CQ, Ilany J, Brüning JC, et al. Rad GTPase deficiency leads to cardiac hypertrophy. Circulation 2007;116:2976-83. 
[46] Yada H, Murata M, Shimoda K, Yuasa S, Kawaguchi H, Ieda M, et al. Dominant negative suppression of Rad leads to QT prolongation and causes ventricular arrhythmias via modulation of L-type Ca2+ channels in the heart. Circ Res 2007;101:69-77.

[47] Massiera F, Seydoux J, Geloen A, Quignard-Boulange A, Turban S, Saint-Marc P, et al. Angiotensinogen-deficient mice exhibit impairment of diet-induced weight gain. Endocrinology $2001 ; 142: 5220-5$.

[48] Boschmann M, Ringel J, Klaus S, Sharma AM. Metabolic and hemodynamic responses of adipose tissue to angiotensin II. Obes Res 2001;9:486-91.

[49] Jayasooriya AP, Mathai ML, Walker LL, Begg DP, Denton DA, Cameron-Smith D, et al. Mice lacking angiotensin-converting enzyme have increased energy expenditure, with reduced fat mass and improved glucose clearance. Proc Natl Acad Sci USA. 2008;105:6531-36.

[50] Stucchi P, Cano V, Ruiz-Gayo M, Fernández-Alonso MS. Aliskiren reduces body-weight gain, adiposity and plasma leptin during diet-induced obesity. Br J Pharmacol 2009;158:771-8.

[51] Sui Y, Zhao HL, Fan RR, Guan J, He L, Lee HM, et al. Renin-angiotensin system activation in renal adipogenesis. Am J Physiol Renal Physiol 2010;298:F391-400.

[52] Jones BH, Standrige MK, Moustaid N. Angiotensin II increases lipogenesis in 3T3-L1 and human adipose cells. Endocrinology 1997;138:1512-9. 
[53]Schwenk RW, Dirkx E, Coumans WA, Bonen A, Klip A, Glatz JFC, et al. Requierements for distinct vesicle-associated membrane proteins in insulin- and AMP-activated protein kinase (AMPK)-induced translocation of GLUT4 and CD36 in cultured cardiomyocytes. Diabetologia 2010;53:2209-19

[54] Khairallah RJ, Khairallah M, Gélinas R, Bouchard B, Young ME, Allen BG, et al. Cyclic GMP signalling in cardiomyocytes modulates fatty acid trafficking and prevents triglyceride accumulation. J Mol Cell Cardiol 2008;45:230-9.

[55]Glatz JF, Bonen A. Ouwens DM, Luiken JJ. Regulation of sarcolemmal transport of substrates in the healthy and diseased heart. Cardiovasc Drug Ther 2006; 20:471-6

[56] Moyers JS, Bilan PJ, Reynet C, Kahn CR. Overexpression of RAD inhibits glucose uptake in cultured muscle and fat cells. J Biol Chem 1996;271:23111-6.

[57] Ilany J, Bilan PJ, Kapur S, Caldwell JS, Patti ME, Marette A, et al. Overexpression of Rad in muscle worsens diet-induced insulin resistance and glucose intolerance and lowers plasma triglyceride levels. Proc Natl Acad Sci USA 2006;103:4481-6.

[58] Zhao G, Jeoung NH, Burgess SC, Rosaaen-Stowe KA, Inagaki T, Latif S, et al.

Overexpression of pyruvate dehydrogenase kinase 4 in heart perturbs metabolism and exacerbates calcineurin-induced cardiomyopathy. Am J Physiol Heart Circ Physiol 2008;294:H936-43.

[59] Planavila A, Laguna JC, Vázquez-Carrera M. Nuclear factor-kappaB activation leads to down-regulation of fatty acid oxidation during cardiac hypertrophy. J Biol Chem 2005;280:1746471. 
[60] Smith EM, Zhang Y, Baye TM, Gawrieh S, Cole R, Blangero J, et al. INSIG1 influences obesity-related hypertriglyceridemia in humans. J Lipid Res 2010;51:701-8.

[61] Ka SO, Kim KA, Kwon KB, Park JW, Park BH. Silibinin attenuates adipogenesis in 3T3-L1 preadipocytes through a potential upregulation of the insig pathway. Int J Mol Med 2009;23:633-7.

[62] Qin X, Xie X, Fan Y, Tian J, Guan Y, Wang X, et al. Peroxisome proliferator-activated receptor-delta induces insulin-induced gene-1 and suppresses hepatic lipogenesis in obese diabetic mice. Hepatology 2008;48:432-41.

[63] Engelking LJ, Liang G, Hammer RE, Takaishi K, Kuriyama H, Evers BM, et al. Schoenheimer effect explained-feedback regulation of cholesterol synthesis in mice mediated by Insig proteins. J Clin Invest 2005;115:2489-98.

[64] Liu X, Li Y, Wang L, Zhao Q, Lu X, Huang J, et al. The INSIG1 gene, not the INSIG2 gene, associated with coronary heart disease: tagSNPs and haplotype-based association study. The Beijing Atherosclerosis Study. Thromb Haemost 2008;100:886-92.

[65] Miranda M, Escoté X, Alcaide MJ, Solano E, Ceperuelo-Mallafré V, Hernández P, et al. Lpin1 in human visceral and subcutaneous adipose tissue: similar levels but different associations with lipogenic and lipolytic genes. Am J Physiol Endocrinol Metab 2010;299:E308-17.

[66] Burgdorf C, Hänsel L, Heidbreder M, Jöhren O, Schütte F, Schunkert H, et al. Suppression of cardiac phosphatidate phosphohydrolase 1 activity and lipin mRNA expression in Zucker diabetic 
fatty rats and humans with type 2 diabetes mellitus. Biochem Biophys Res Commun 2009;390:165-70.

[67] Yamakawa T, Sugimoto K, Whitson RH, Itakura K. Modulator recognition factor 2 regulates triglyceride metabolism in adipocytes. Biochem Biophys Res Commun 2010;391:277-81.

[68]van der Vusse GJ, van Bilsen M, Glatz JFC. Cardiac fatty acid uptake and transport in health and disease. Cardiovasc Res 2000;45:279-93.

[69] Nussberger J, Aubert JF, Bouzourene K, Pellegrin M, Hayoz D, Mazzolai L. Renin inhibition by aliskiren prevents atherosclerosis progression: comparison with irbesartan, atenolol, and amlodipine. Hypertension 2008;51:1306-11.

[70] Verdecchia P, Angeli F, Mazzotta G, Gentile G, Reboldi G. The renin angiotensin system in the development of cardiovascular disease: role of aliskiren in risk reduction. Vasc Health Risk Manag 2008;4:971-81.

[71] Gadbut AP, Wu L, Tang D, Papageorge A, Watson JA, Galper JB. Induction of the cholesterol metabolic pathway regulates the farnesylation of Ras in embryonic chick heart cells: a new role for Ras in regulating the expression of muscarinic receptors and G proteins. EMBO J 1997;16:725060.

[72]Tsujikawa H, Song Y, Watanabe M, Masumiya H, Gupte SA, Ochi R, et al. Cholesterol depletion modulates basal L-type $\mathrm{Ca} 2+$ current and abolishes its $\beta$-adrenergic enhancement in ventricular myocytes. Am J Physiol Heart Circ Physiol 2008;294:H285-92. 
[73]Purcell NH, Wilkins BJ, York A, Saba-El-Leil MK, Mecloche S, Robbins J, et al. Genetic inhibition of cardiac ERK1/2 promotes stress-induced apoptosis and heart failure but has no effect on hypertrophy in vivo. Proc Natl Acad Sci USA 2007;104:14074-9.

[74]Daniels A, van Bilsen M, Goldschmeding R, van der Vusse GJ, van Nieuwenhoven FA. Connective tissue growth factor and cardiac fibrosis. Acta Physiol (Oxf) 2009;195:321-38.

[75] Singh VP, Le B, Bhat VB, Baker KM, Kumar R. High-glucose-induced regulation of intracellular ANG II synthesis and nuclear redistribution in cardiac myocytes. Am J Physiol Heart Circ Physiol 2007;293:H939-48.

[76] Tsai CT, Lai LP, Hwang JJ, Chen WP, Chiang FT, Hsu KL, et al. Renin-angiotensin system component expression in the HL-1 atrial cell line and in a pig model of atrial fibrillation. J Hypertens 2008;26:570-82.

[77] Saris JJ, Derkx FH, Lamers JM, Saxena PR, Schalekamp MA, Danser AH. Cardiomyocytes bind and activate native human prorenin: role of soluble mannose 6-phosphate receptors. Hypertension 2001;37:710-5.

[78] Huang J, Siragy HM. Regulation of (pro)renin receptor expression by glucose-induced mitogen-activated protein kinase, nuclear factor-kappaB, and activator protein-1 signaling pathways. Endocrinology 2010;151:3317-25.

[79] Burcklé CA, Danser JAH, Müller DN, Garrelds IM, Gasc JM, Popova E, et al. Elevated blood pressure and heart rate in human renin receptor transgenic rats. Hypertension 2006;47:552-6. 
[80] Clausmeyer S, Reinecke A, Farrenkopf R, Unger T, Peters J. Tissue-specific expression of a

rat renin transcript lacking the coding sequence for the prefragment and its stimulation by myocardial infarction. Endocrinology 2000;141:2963-70.

[81] Danser AHJ. The increase in renin during renin inhibition:does it result in harmful effects by the (pro)renin receptor?. Hypertension Res 2010;33:4-10.

[82] Bogazzi R, Raggi F, Ultimieri F, Russo D, D’Alessio A, Manariti A, et al. Regulation of cardiac fatty acid metabolism in transgenic mice overexpressing bovine GH. J Endocrinol 2009;201:419-27.

[83] Turcotte LP, Raney MA, Todd MK. ERK1/2 inhibition prevents contraction-induced increase in plasma membrane FAT/CD36 content and FA uptake in rodent muscle. Acta Physiol Scand 2005;184:131-9. 


\section{Figure Legends}

Figure 1.A. MTT assays showed that $1 \mathrm{nmol} / \mathrm{L}-50 \mu \mathrm{mol} / \mathrm{L}$ of aliskiren did not affect viability of HL-1 cells at 24 or $48 \mathrm{~h}(\mathrm{n}=3)$. FBS was used as a positive control. B. FACS analysis of HL-1 cells treated with $50 \mu \mathrm{mol} / \mathrm{L}$ aliskiren for $48 \mathrm{~h}$ and stained with propidium iodide (representative experiment of $\mathrm{n}=3$ shown), showing number of cells $v s$ DNA content (indicating cells that are apoptotic (Apo), in $\mathrm{G}_{0} / \mathrm{G}_{1}(2 \mathrm{n})$ or $\mathrm{S} / \mathrm{M}(4 \mathrm{n})$ mitotic stages. C. FACS analysis of BODIPY-labelled dodecanoic acid by HL-1 and primary-cultured neonatal-rat cardiomyocytes after dose-response $(1-50 \mu \mathrm{mol} / \mathrm{L})$ treatments with aliskiren. Aliskiren induced dodecanoic-acid uptake after 30min in HL-1 cardiomyocytes at doses of $20 \mu \mathrm{mol} / \mathrm{L}(1.57 \pm 0.35, \mathrm{p}<0.05, \mathrm{n}=4)$ and $50 \mu \mathrm{mol} / \mathrm{L}(1.60 \pm 0.38$, $\mathrm{p}<0.05, \mathrm{n}=4)(\mathbf{C . 1})$, and after $120 \mathrm{~min}$ in primary cultures of neonatal-rat cardiomyocytes at doses of $10 \mu \mathrm{mol} / \mathrm{L}(1.47 \pm 0.14, \mathrm{p}<0.05, \mathrm{n}=4)$ and $50 \mu \mathrm{mol} / \mathrm{L}(1.86 \pm 0.13, \mathrm{p}<0.001, \mathrm{n}=4) .100 \mathrm{nmol} / \mathrm{L}$ insulin was used as a positive control in neonatal-rat primary cardiomyocytes $(1.53 \pm 0.21, \mathrm{p}<0.05$, $\mathrm{n}=4)\left(\right.$ C.2). Data are shown as mean $\pm \mathrm{SD} ;{ }^{*} p<0.05 ; * * * p<0.001$.

Figure 2. Immunocytochemistry and confocal analyses showed that aliskiren increased the plasmamembrane localization of the fatty-acid transporter CD-36, in primary-cultured adult-human (A-C: controls; D-F: $50 \mu \mathrm{mol} / \mathrm{L}$ aliskiren; examples indicated with arrows; G-I: $10 \mu \mathrm{mol} / \mathrm{L}$ aliskiren; examples indicated with arrows) and neonatal-rat (J-L: controls; M-O: 50 $\mu \mathrm{mol} / \mathrm{L}$ aliskiren; examples indicated with arrows) cardiomyocytes after 30min. The dose of $10 \mu \mathrm{mol} / \mathrm{L}$ of aliskiren caused a complementary decrease of the amount of the glucose transporter Glut- 4 at the cytoplasm/plasma membrane compartment of neonatal-rat cardiomyocytes at 30min (P-R: controls; S-U; 10 $\mu \mathrm{mol} / \mathrm{L}$ aliskiren; examples indicated with arrows). MAIN PANEL: left column (A, D, G, J, M, P, S): antibody expression; middle column (B, E, H, K, N, Q,T): TO-PRO-3 nuclear marker; right column $(\mathbf{C}, \mathbf{F}, \mathbf{I}, \mathbf{L}, \mathbf{O}, \mathbf{R}, \mathbf{U})$ : merge. LEFT OF MAIN PANEL: D, G, M and $\mathrm{S}$ are shown at higher magnification. Scale bar: $50 \mu \mathrm{m}$. 
Figure 3. Aliskiren induced intracellular phosphorylation of ERK1/2 in primary-cultured cardiomyocytes. Responses in neonatal-rat cardiomyocytes were dose-dependent at $5 \mathrm{~min}(\mathbf{A}$ : statistical analysis which shows that $50 \mu \mathrm{mol} / \mathrm{L}$ aliskiren produced the maximum response $(1.45 \pm 0.51, \mathrm{p}<0.05, \mathrm{n}=4) ; \mathbf{D}$ : representative western blot), and time-dependent at $50 \mu \mathrm{mol} / \mathrm{L}$ (B: statistical analysis which shows that the maximum response was at $5 \min (1.42 \pm 0.33, \mathrm{p}<0.001$, n=8); E: representative western blot). ERK1/2 was phosphorylated in adult-human cardiomyocytes treated for 5min with 50 $\mathrm{mol} / \mathrm{L}$ aliskiren; C: statistical analysis, showing that ERK1/2 phosphorylation was not significantly affected by renin treatment either in human $(\mathbf{C . 1})$ or in neonatal rat (C.2) cardiomyocytes; F.1: representative western blot for C.1. F.2: representative western blot for C.2. Aliskiren also induced phosphorylation of ERK1/2 dose- (G.1) and timedependently (G.2) in HL-1 cardiomyocytes. Data are expressed as mean \pm SD; ${ }^{*} p<0.05 ; * * p<0.01$; $* * * p<0.001$.

Figure 4. Global, functional and network analyses of gene expression data from the rat Gene 1.0 ST microarray using Gene Ontology and IPA software. A: global summary of results; left panel: distribution of genes altered in cardiomyocytes by aliskiren treatment, according to biological function; right panel: distribution of genes according to molecular type. B: interactive network of most significantly altered genes (IPA network score $=15$ ) in cardiomyocytes treated with aliskiren (relative to untreated cells). Genes and gene products are represented by their common abbreviated names and lines represent established direct (solid lines) or indirect (dashed lines) interactions as well as the nature of the interaction (e.g. binding (straight line), activation (arrow), inhibition (truncated line)). Genes that were significantly over-expressed in the aliskiren-treated group (relative to control) are highlighted in black; reduced expression is denoted in grey; white indicates no expression change. The shape of each gene 'node' denotes the function of the gene product. 
Figure 5. Real-time qPCR and immunoblotting confirmed the microarray analysis for lipid and glucose metabolism, in neonatal-rat cardiomyocytes with $50 \mu \mathrm{mol} / \mathrm{L}$ aliskiren. After a $3 \mathrm{~h}$ treatment mRNA expression of Insig1, Lpin1 and Pdk4 (involved in lipid metabolism) were all significantly increased (Insig1: 204 $\pm 47 \%$ control, p<0.01; Lpin1: 212 $\pm 80 \%$ control, $\mathrm{p}<0.05 ;$ Pdk4: 163 $\pm 48 \%$ control, $\mathrm{p}<0.05)(\mathbf{A})$, but of Rrad (involved in glucose metabolism) and Arid5a were decreased (Rrad: $29 \pm 15 \%$ control, $\mathrm{p}<0.001$; Arid5a 74 $\pm 10 \%$ control, $\mathrm{p}<0.05)(\mathbf{B})($ each $n=5)$. Similar results were obtained for protein expression of Insig1, Lpin1, Pdk4 and Rrad after 6h of treatment: Insig1

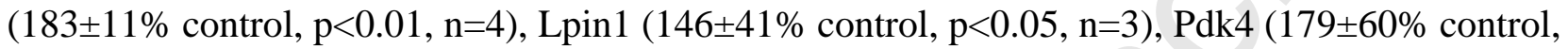
$\mathrm{p}<0.05, \mathrm{n}=5)$ and $\operatorname{Rrad}(50 \pm 18 \%$ control, $\mathrm{p}<0.05, \mathrm{n}=4)$ in neonatal rat cardiomyocytes $(\mathbf{C . 1}$ : representative western blots; D: statistical analysis;); and for the protein assayed, Lpin1, in human primary cardiomyocytes (C.2). Data are expressed as mean $\pm \mathrm{SD} ; *_{p}<0.05$; ** $p<0.01$; ***p $p<0.001$.

Figure 6. Real-time PCR and western blotting confirmed the microarray analysis with respect to cholesterol biosynthesis. mRNA levels (A) of Hmgcs1 (199 $\pm 38 \%$ control, $p<0.05, n=5), H m g c r$ $(167 \pm 34 \%$ control, $\mathrm{p}<0.05, \mathrm{n}=5)$, Fdft1 $(195 \pm 35 \%$ control, $\mathrm{p}<0.01, \mathrm{n}=5)$, Lss $(130 \pm 21 \%$ control, $\mathrm{p}<0.05, \mathrm{n}=5)$ and Dhcr7 $(227 \pm 47 \%$ control, $\mathrm{p}<0.01, \mathrm{n}=5)$ were increased in neonatal-rat cardiomyocytes treated for $3 \mathrm{~h}$ with $50 \mu \mathrm{mol} / \mathrm{L}$ aliskiren. There were similar alterations in protein levels at 3h (B): Hmgcs1 (185 $\pm 31 \%$ control, $\mathrm{p}<0.05, \mathrm{n}=3)$, Hmgcr $(144 \pm 19 \%$ control, $\mathrm{p}<0.05$, $\mathrm{n}=4)$, Fdft $1(144 \pm 11 \%$ control, $\mathrm{p}<0.05, \mathrm{n}=3)$, Lss $(231 \pm 14 \%$ control, $\mathrm{p}<0.01, \mathrm{n}=3)$, and Dhcr7 $(161 \pm 23 \%$ control, $\mathrm{p}<0.05, \mathrm{n}=3)$. Representative western blots are shown for neonatal-rat $(\mathbf{C . 1})$ and adult-human (C.2) cardiomyocytes. Data are shown as mean $\pm \mathrm{SD} ; * p<0.05$; ** $p<0.01$. 
Aliskiren can induce changes in fatty-acid and glucose uptake and expression of key enzymes of lipid and cholesterol metabolism in cultured cardiomyocytes
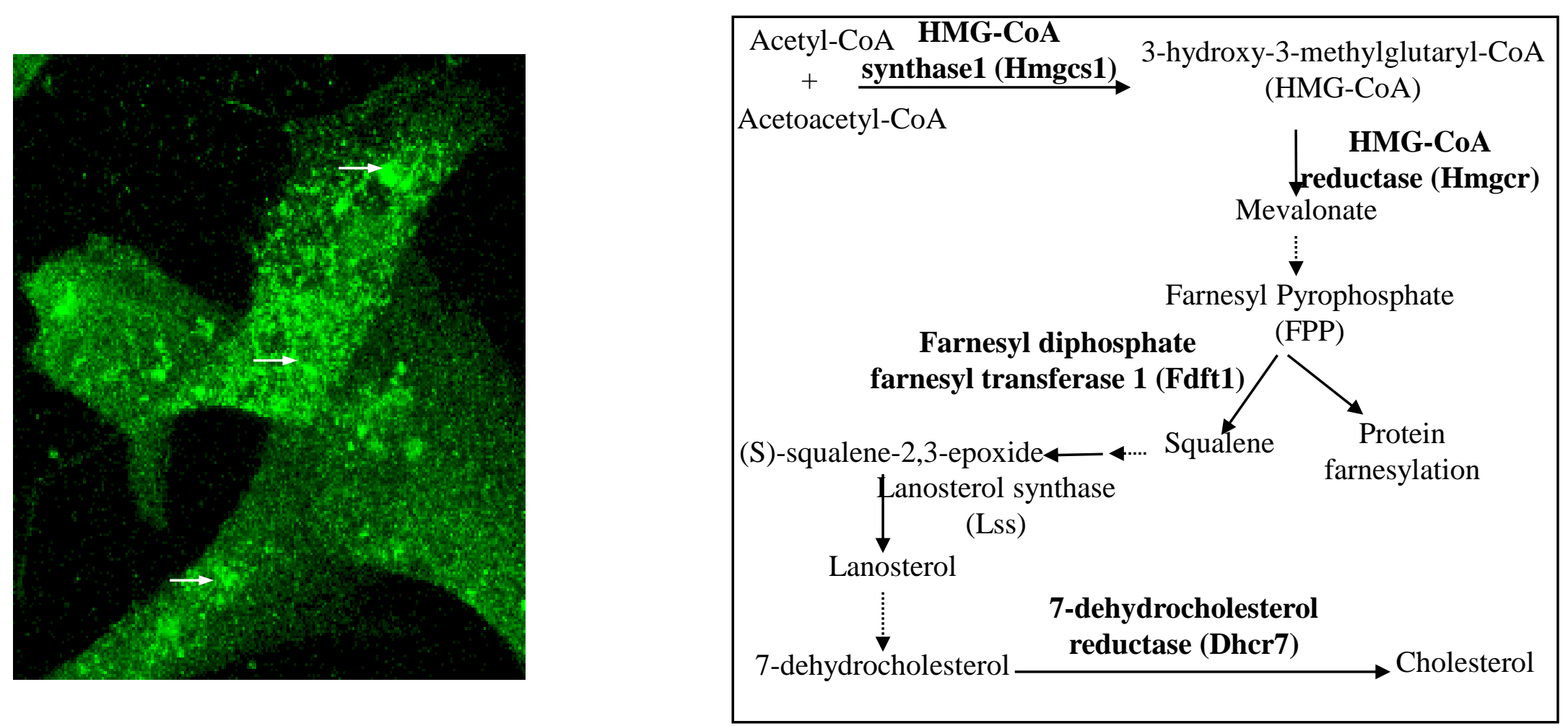

Confocal microphotography showing upregulation of the expression of fatty-acid transporter CD36 in the membrane of human cardiomyocytes treated with aliskiren

Pathway of cholesterol biosynthesis with the enzymes affected by aliskiren in bold 
Table 1

\begin{tabular}{|c|c|c|c|c|c|}
\hline & \multicolumn{5}{|c|}{ Dose of aliskiren (30min treatment) } \\
\hline & $0 \mu \mathrm{mol} / \mathrm{L}$ & $5 \mu \mathrm{mol} / \mathrm{L}$ & $10 \mu \mathrm{mol} / \mathrm{L}$ & $20 \mu \mathrm{mol} / \mathrm{L}$ & $50 \mu \mathrm{mol} / \mathrm{L}$ \\
\hline & \multicolumn{5}{|c|}{ Plasma membrane expression (\% and total cell number) } \\
\hline CD-36 (human) & $14.8(210)$ & - & $44.0(175)$ & - & $71.7(145)$ \\
\hline CD-36 (rat) & $17.0(171)$ & - & $59.2(142)$ & - & $82.0(152)$ \\
\hline Glut-4 (rat) & $27.5(138)$ & $12.1(132)$ & $10.1(138)$ & $8.6(139)$ & $7.3(96)$ \\
\hline $\begin{array}{c}\text { Cytoplasm/plasma } \\
\text { membrane:nuclear ratio } \\
\text { for Glut-4(rat) distribution } \\
(\text { mean } \pm \text { SEM })\end{array}$ & $0.993 \pm 0.043$ & $0.873 \pm 0.056$ & $0.877 \pm 0.009$ & $0.857 \pm 0.010$ & $0.804 \pm 0.014$ \\
\hline p-value vs control & ns & ns & $\mathrm{p}<0.01$ & $\mathrm{p}<0.01$ & $\mathrm{p}<0.001$ \\
\hline Total cell number & 138 & 132 & 138 & 139 & 96 \\
\hline
\end{tabular}

Table 1. Plasma membrane expression of CD-36 and Glut-4 as a function of total number of cells, species of cardiomyocyte origin and dose of aliskiren. 
Table 2

\begin{tabular}{ll}
\hline \multicolumn{1}{c}{ Biological functions } & p-value \\
\hline Lipid Metabolism & $2.44 \times 10^{-5}$ \\
Small Molecule Biochemistry & $2.44 \times 10^{-5}$ \\
Vitamin and Mineral Metabolism & $2.44 \times 10^{-5}$ \\
Cellular Development & $4.35 \times 10^{-5}$ \\
Cellular Growth and Proliferation & $1.31 \times 10^{-4}$ \\
Cell Cycle & $1.72 \times 10^{-4}$ \\
Connective Tissue Development and Function & $1.72 \times 10^{-4}$ \\
Cardiovascular System Development and Function & $2.34 \times 10^{-4}$ \\
Organismal Development & $2.34 \times 10^{-4}$ \\
Cell Death & $3.22 \times 10^{-4}$ \\
Organ Morphology & $4.19 \times 10^{-4}$ \\
Embryonic Development & $5.44 \times 10^{-4}$ \\
Hematological Disease & $6.13 \times 10^{-4}$ \\
Metabolic Disease & $6.13 \times 10^{-4}$ \\
Cell Morphology & $7.40 \times 10^{-4}$ \\
\hline & p-value \\
\hline Cardiac Proliferation & $9.41 \times 10^{-3}$ \\
Heart Failure & $3.05 \times 10^{-2}$ \\
Cardiac Damage & $3.54 \times 10^{-2}$ \\
Cardiac Enlargement & $3.54 \times 10^{-2}$ \\
\hline \multirow{2}{*}{ Cardiac Necrosis/Cell Death } & $3.54 \times 10^{-2}$ \\
\hline & $3.83 \times 10^{-2}$ \\
\hline
\end{tabular}

Table 2. Funtional analysis of microarray using IPA identified the biological functions and cardiac alterations that were most significant to the data set. Genes for the biological functions met $\mathrm{p}$-value $<0.001$ and genes for cardiac alterations met $p$-value $<0.05$. 
A
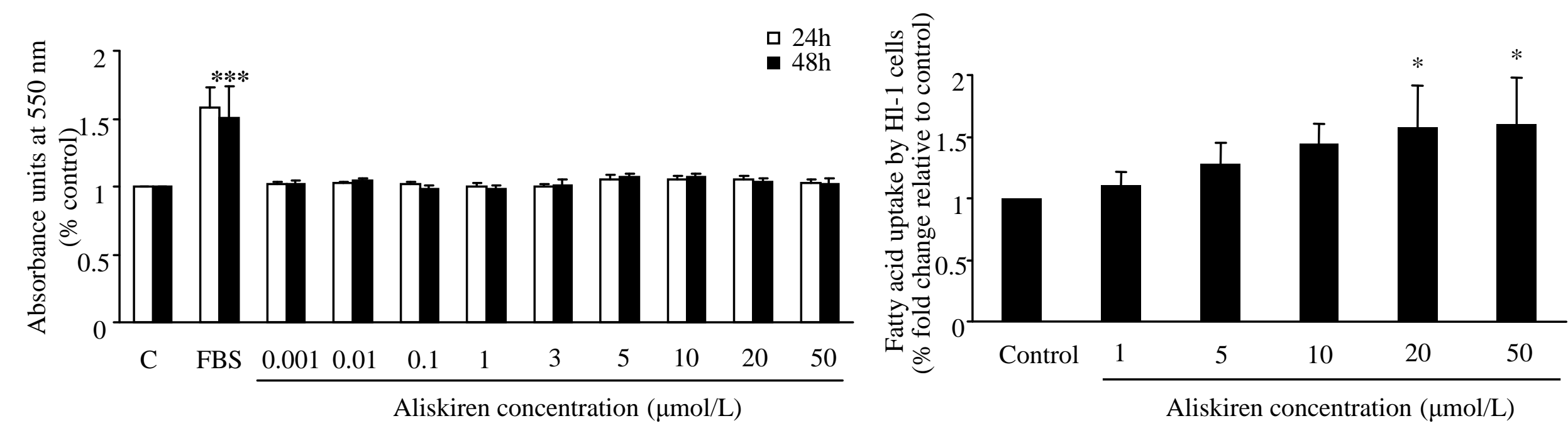

B
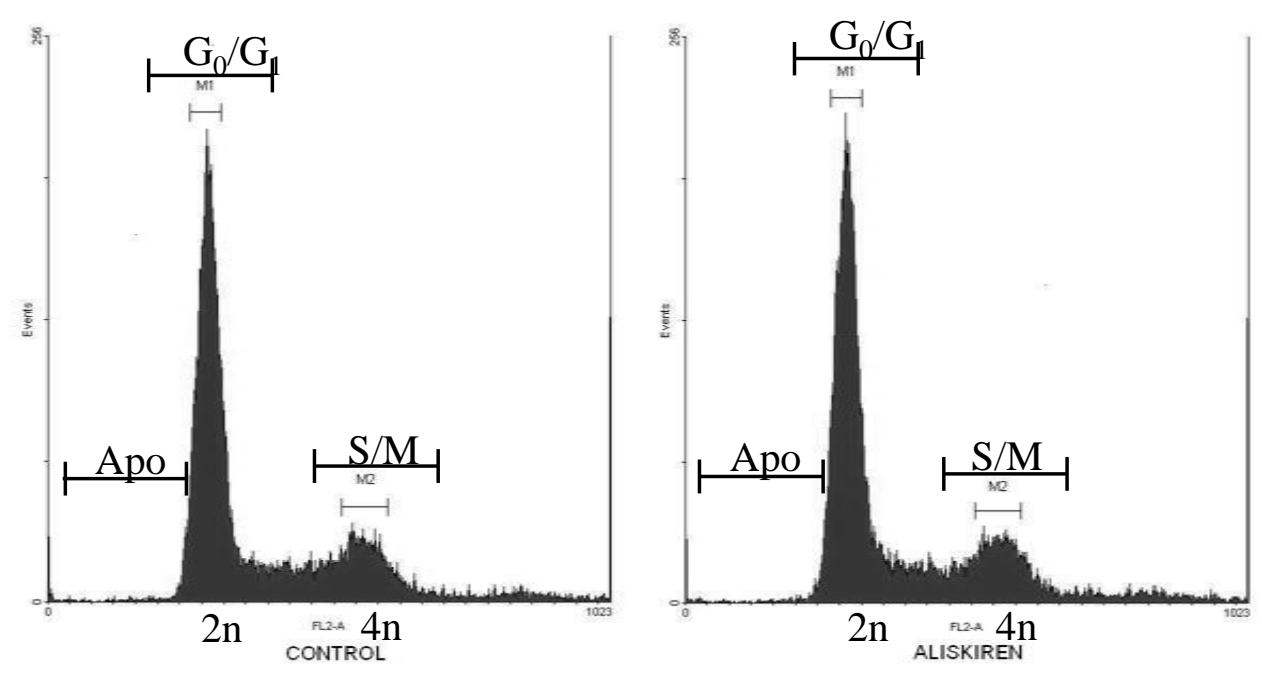

C. 2

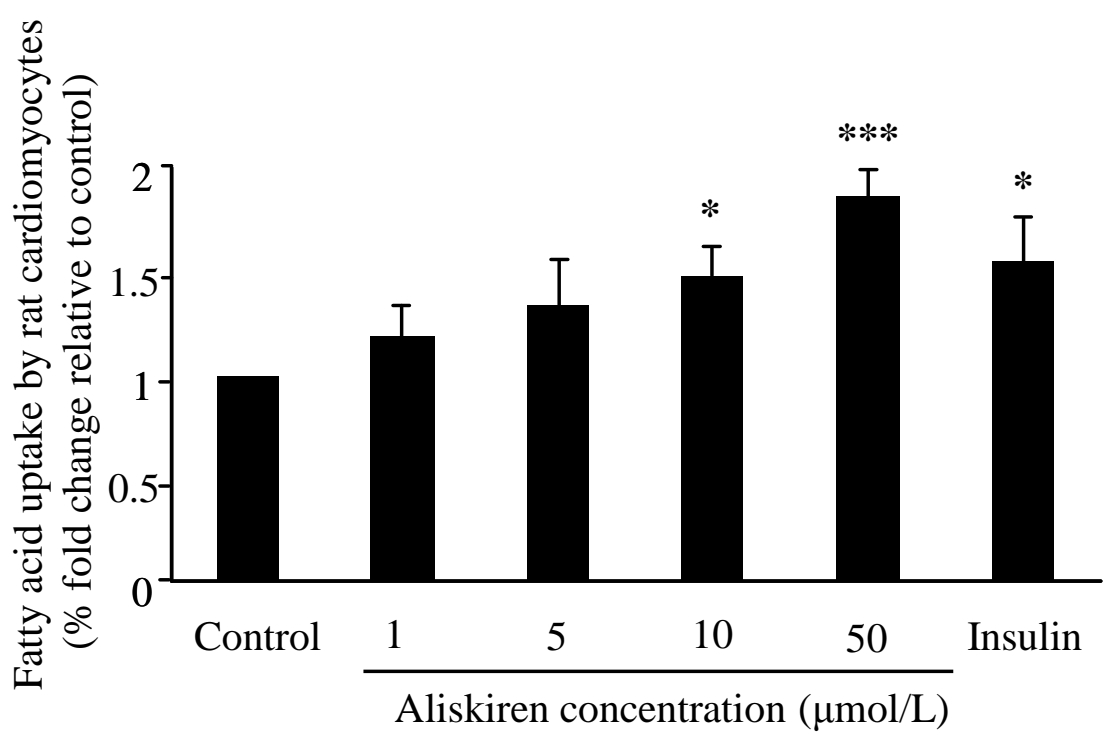




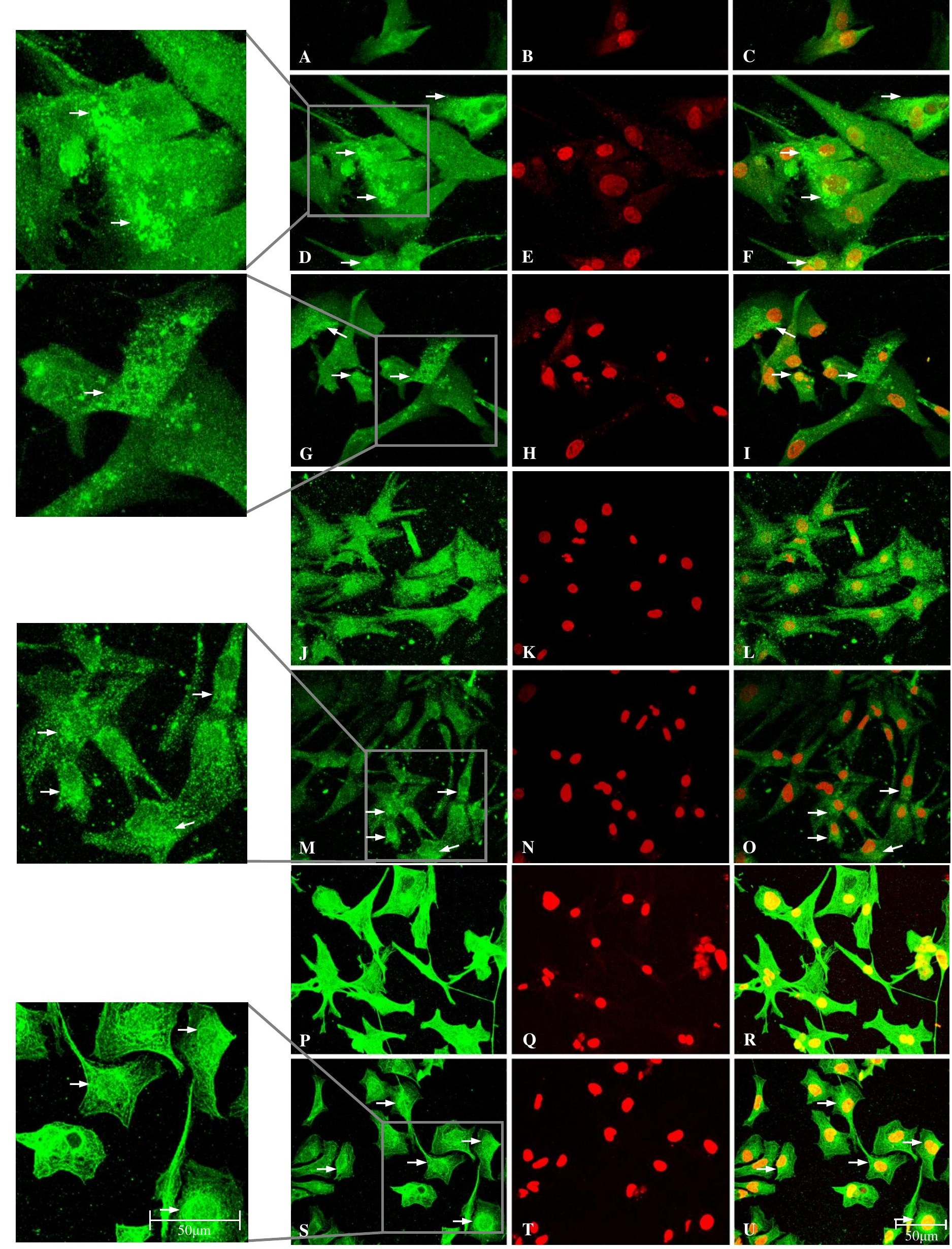


Figtipgrese 3

A Rat primary-cultured cardiomyocytes (Aliskiren treatment for $5 \mathrm{~min}$ )

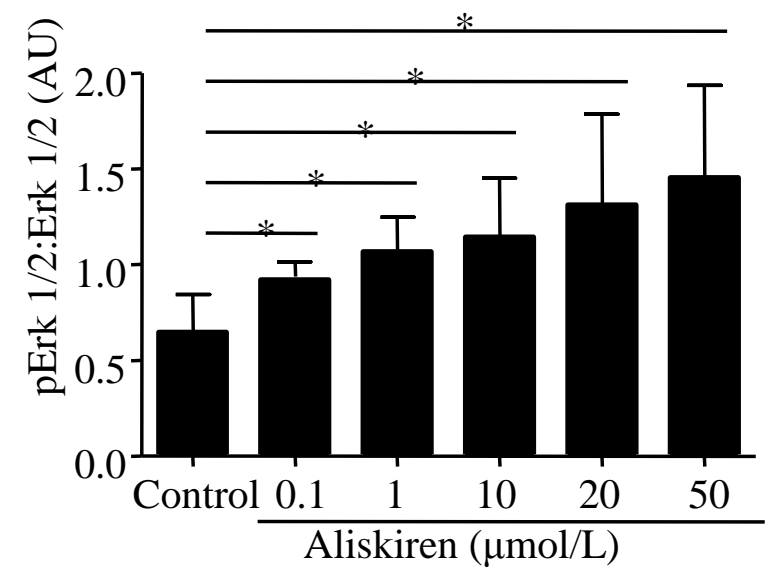

B Rat primary-cultured cardiomyocytes (Aliskiren 50 $\mu \mathrm{mol} / \mathrm{L}$ )

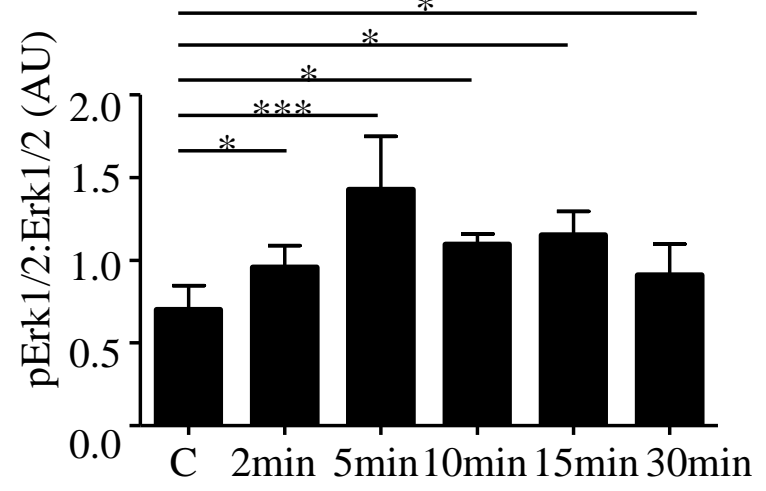

$\mathrm{C}$

C.1 Human primary-cultured cardiomyocytes

(50 $\mu \mathrm{mol} / \mathrm{L}$ treatment for $5 \mathrm{~min})$

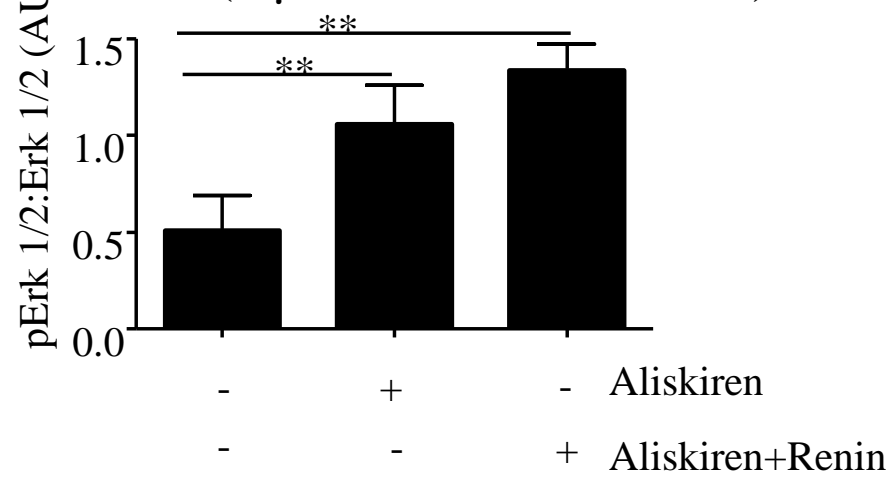

C.2 Rat primary-cultured cardiomyocytes
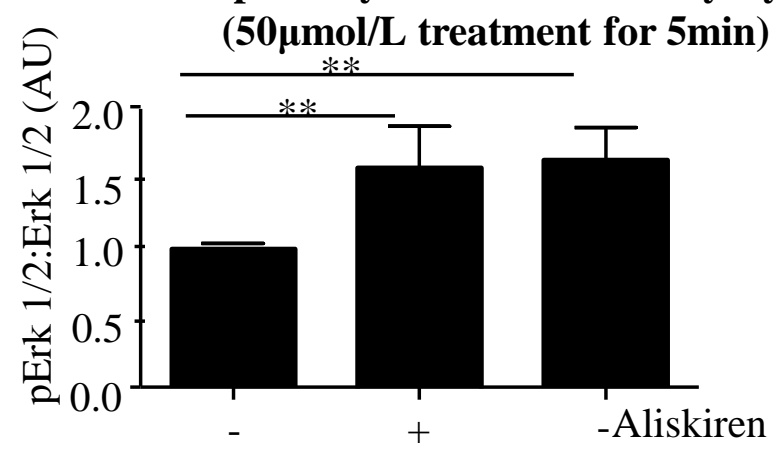

D Rat primary-cultured cardiomyocytes (Aliskiren treatment for $5 \mathrm{~min}$ )

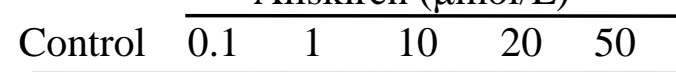

pErk 1/2

Erk 1/2

\begin{tabular}{cccccc} 
& \multicolumn{5}{c}{ Aliskiren $(\mu \mathrm{mol} / \mathrm{L})$} \\
\cline { 2 - 6 } Control & 0.1 & 1 & 10 & 20 & 50
\end{tabular}

E Rat primary-cultured cardiomyocytes (Aliskiren 50 $\mu \mathrm{mol} / \mathrm{L}$ )

Control $2 \mathrm{~min} 5 \mathrm{~min}$ 15min 30min

pErk 1/2

Erk 1/2

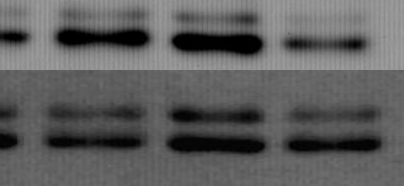

F.1 Human primary-cultured cardiomyocytes $(50 \mu \mathrm{mol} / \mathrm{L}$ treatment for $5 \mathrm{~min})$

Control Aliskiren Aliskiren + Renin

pErk $1 / 2$

Erk $1 / 2$

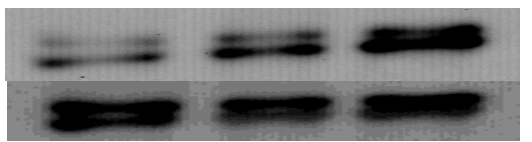

F.2 Rat primary-cultured cardiomyocytes (50 $\mathrm{\mu mol} / \mathrm{L}$ treatment for $\mathbf{5 m i n}$ )

Control Aliskiren Aliskiren + Renin

pErk 1/2

Erk 1/2

G.1

HL-1 cardiomyocytes Aliskiren $(\mu \mathrm{mol} / \mathrm{L} ; 5$ min $)$

pErk 1/2

Erk 1/2

G.2

\begin{tabular}{llllll} 
& \multicolumn{4}{c}{ Aliskiren $(\boldsymbol{\mu m o l} / \mathbf{L} ; \mathbf{5}$ min $)$} \\
\cline { 2 - 6 } Control & 0.1 & 1 & 10 & 20 & 50
\end{tabular}


A

Cell stress 4\% Response to nutrients 10\% Cell death 3\% signalling 9\% $\mid \begin{aligned} & \text { Response to drug 2\% } \\ & \text { Others } 4 \%\end{aligned}$ Cell cycle and, migration $8 \%$ Transcription $7 \%$

Differentiation $7 \%$
Biological and cellular processes $26 \%$

Development and morphogenesis $10 \%$

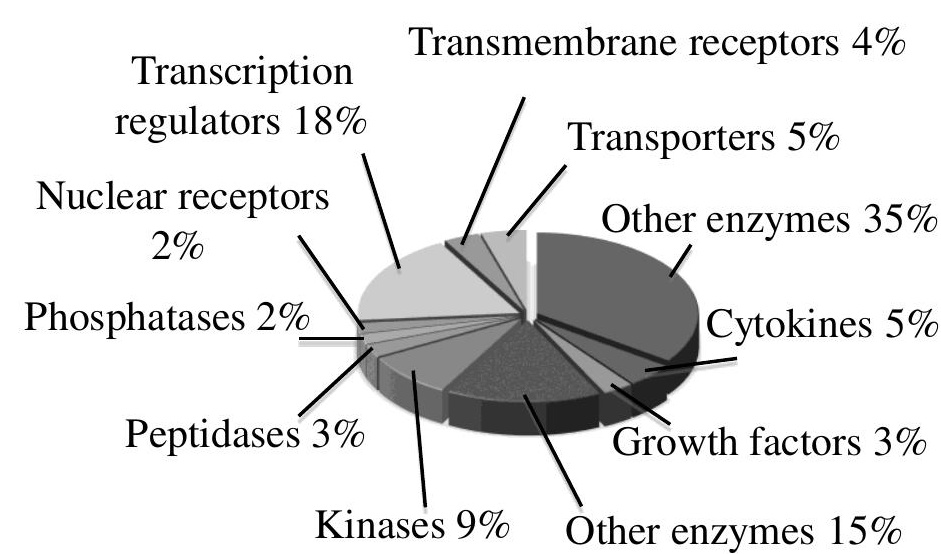

B

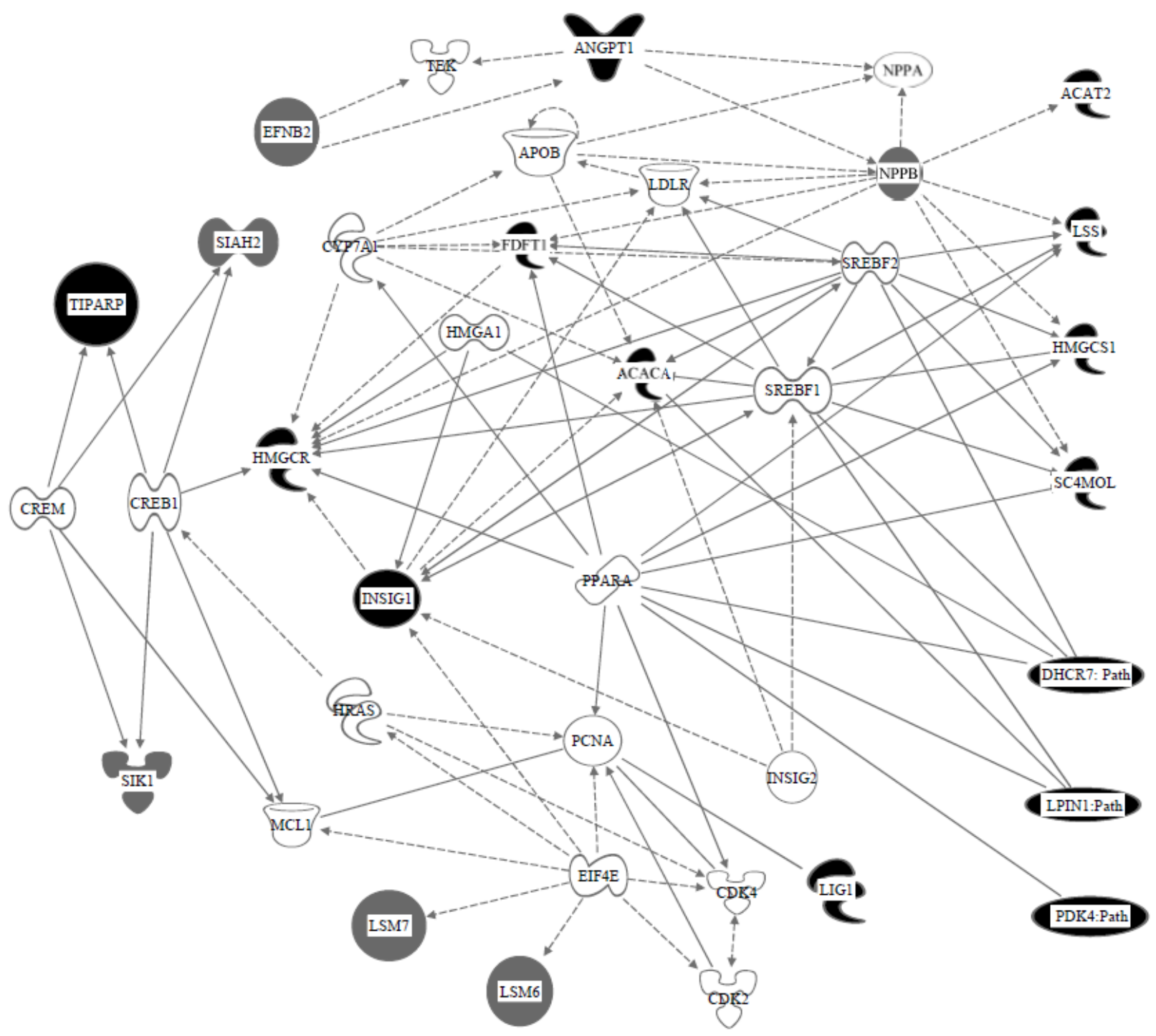

\begin{tabular}{|c|c|c|}
\hline V Cytokine/growth factor & گิ Kinase & $\circlearrowleft$ Translation regulator \\
\hline ६ Enzyme & $\curvearrowright$ Ligand-dependent receptor & $\circlearrowleft$ Path \\
\hline
\end{tabular}


Figure 5

A

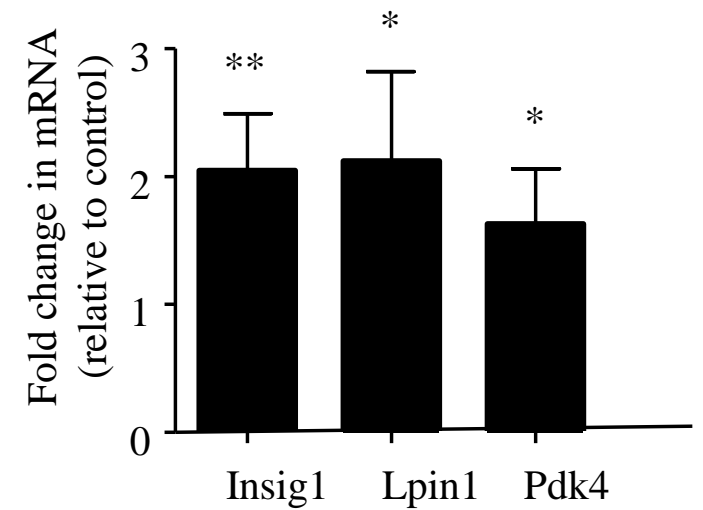

B

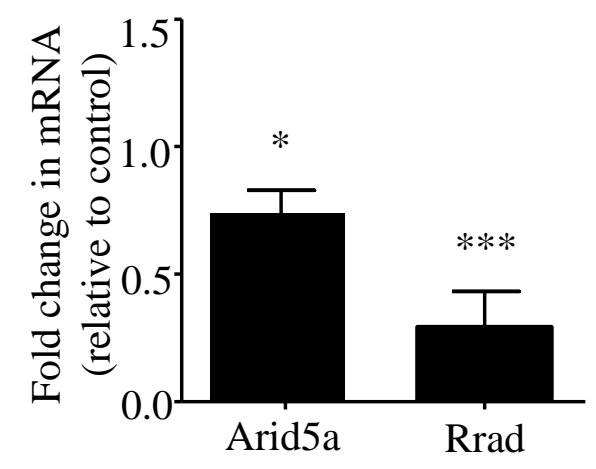

C. 1

Rat

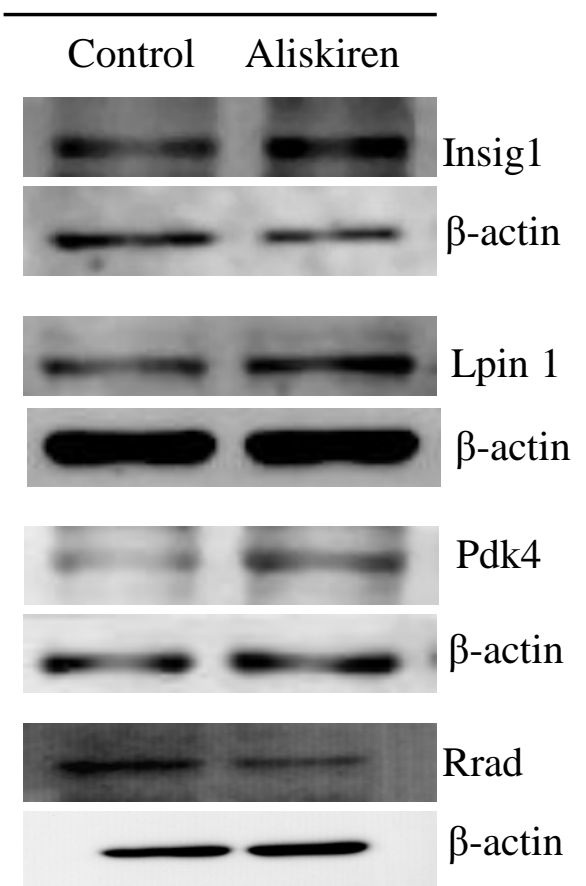

C. 2

Human

D

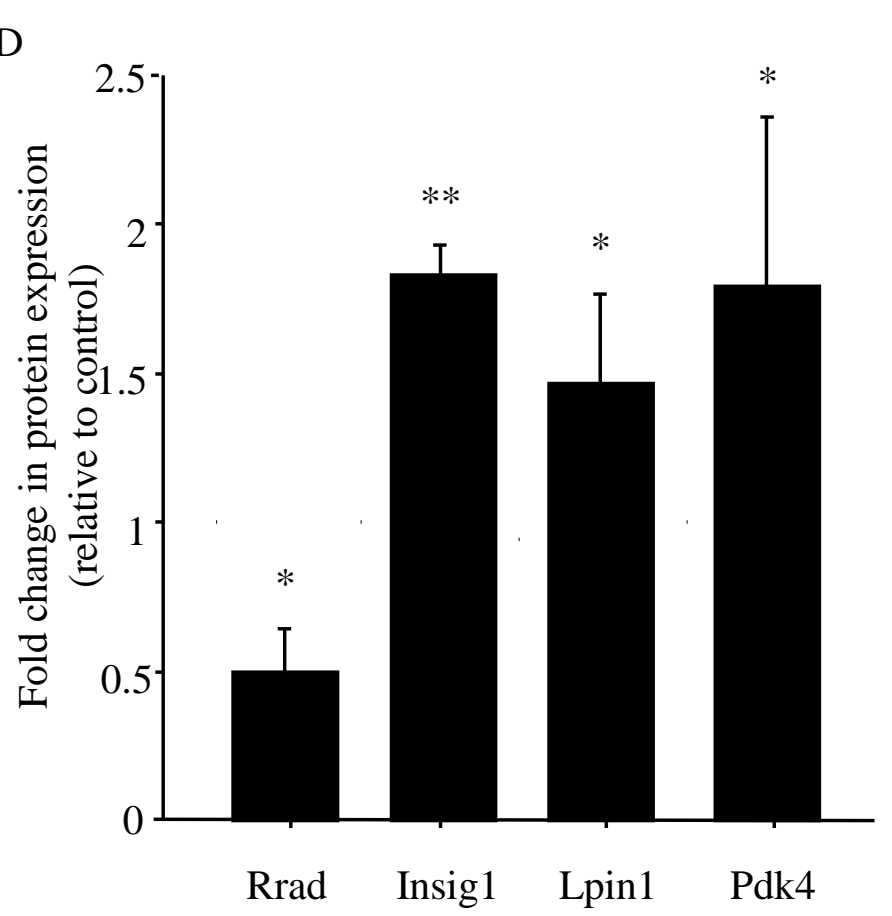

Lpin 1 $\beta$-actin 
Figure 6

A

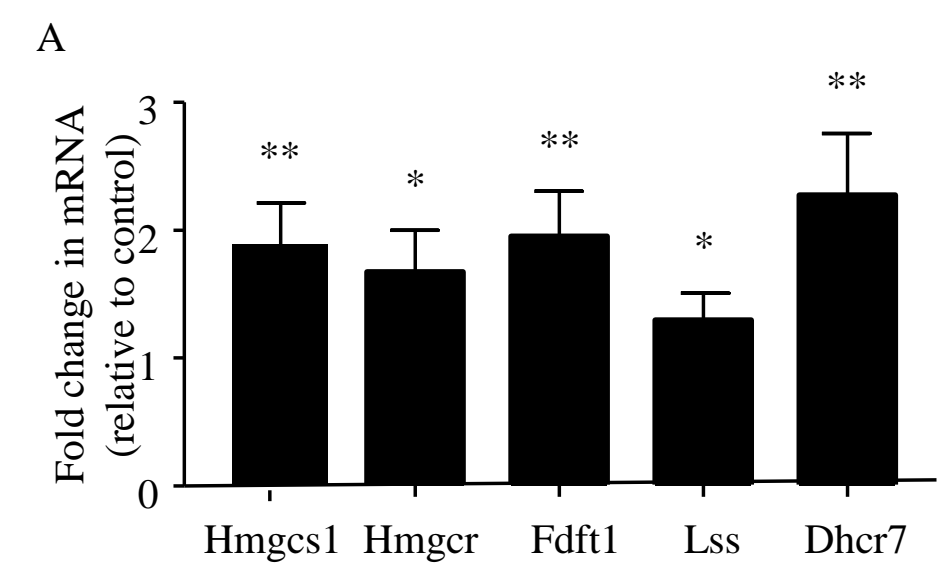

B

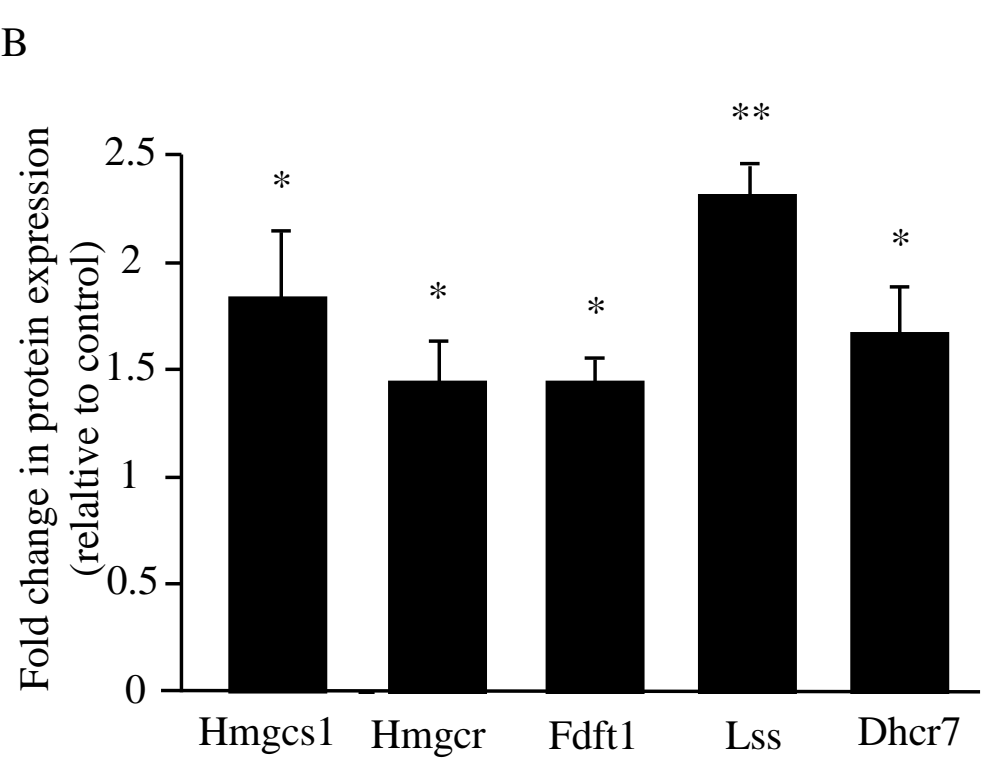

\section{Figure 6}

C. 1

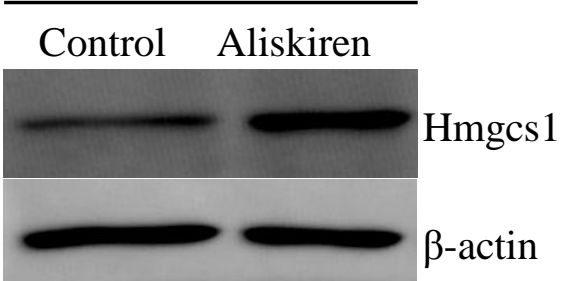

Hmger

$\beta$-actin

Fdft1

$\beta$-actin

Lss

$\beta$-actin

Dhcr7

$\beta$-actin

C.2 Control Aliskiren

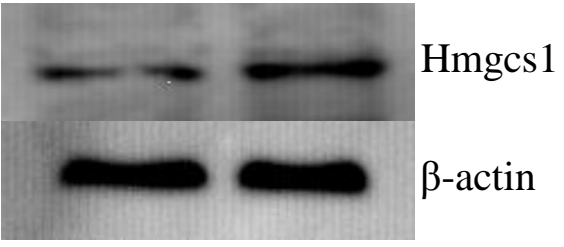

Hmgcr

$\beta$-actin

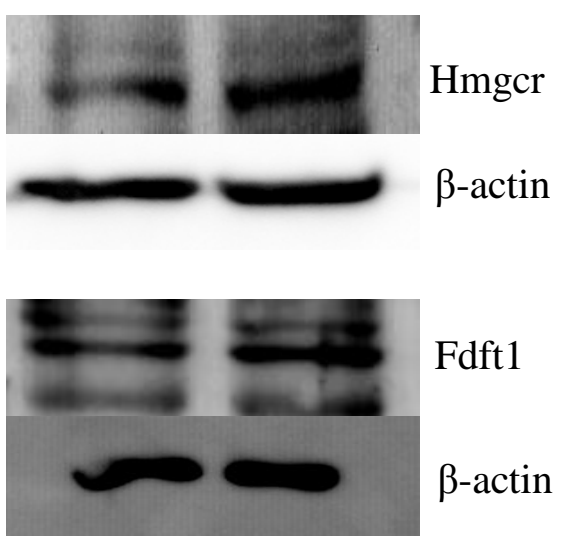

Dhcr7

$\beta$-actin

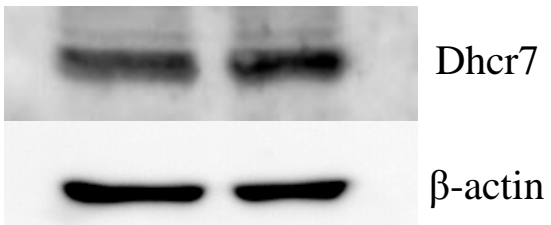

